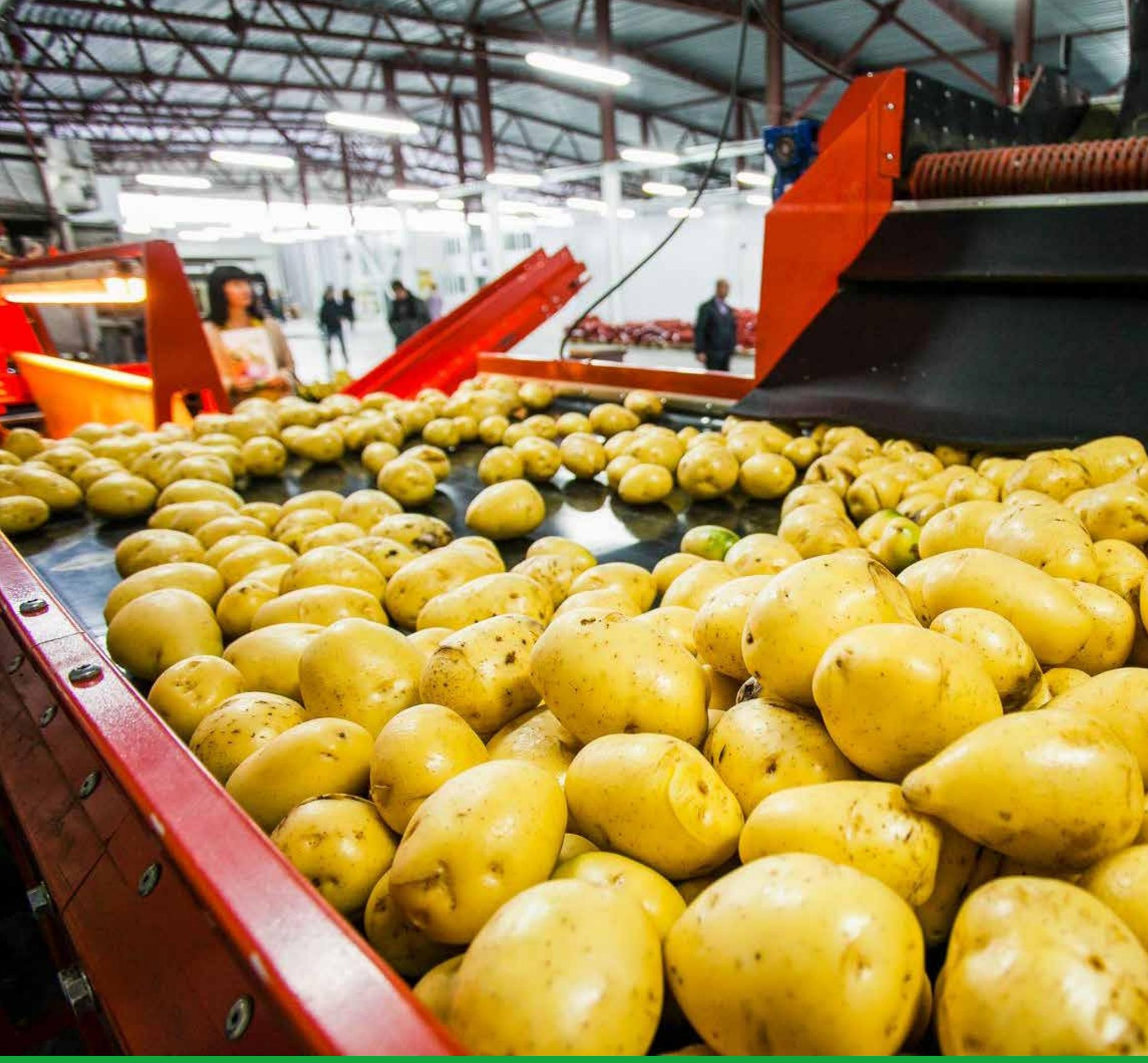

The EU frozen potato product sector: a policy impact assessment for four keyproducing Member States

S.R.M. Janssens, R.A. Jongeneel, A.B. Smit

WAGENINGEN

UNIVERSITY \& RESEARCH 



\section{The EU frozen potato product sector: a policy impact assessment for four key- producing Member States}

S.R.M. Janssens, R.A. Jongeneel, A.B. Smit 
Janssens, S.R.M., R.A. Jongeneel, A.B. Smit, 2021. The EU frozen potato product sector: a policy impact assessment for four key-producing Member States. Wageningen, Wageningen Economic Research, Report 2021-062. 42 pp.; 19 fig.; 12 tab.; 31 ref.

This study showed that neither CAP support from the EU nor Covid-19 support from national governments to producers of frozen potato products (FPP) in Belgium, France, Germany and the Netherlands resulted in competitive advantages compared to FPP-producers outside the EU. Extra-EU export prices were found to be lower than intra-EU export prices, but this was due to market type (free versus contracts), product portfolio and market share.

Key words: Frozen potato products, potato processing, government support, CAP, Covid-19

This report can be downloaded for free at https://doi.org/10.18174/553612 or at www.wur.eu/economic-research (under Wageningen Economic Research publications).

(C) 2021 Wageningen Economic Research

P.O. Box 29703, 2502 LS The Hague, The Netherlands, T +31 (0)70 33583 30,

E communications.ssg@wur.nl, http://www.wur.eu/economic-research. Wageningen Economic Research is part of Wageningen University \& Research.

\section{(cc) BY-NC}

This work is licensed under a Creative Commons Attribution-Non Commercial 4.0 International License.

(c) Wageningen Economic Research, part of Stichting Wageningen Research, 2021

The user may reproduce, distribute and share this work and make derivative works from it. Material by third parties which is used in the work and which are subject to intellectual property rights may not be used without prior permission from the relevant third party. The user must attribute the work by stating the name indicated by the author or licensor but may not do this in such a way as to create the impression that the author/licensor endorses the use of the work or the work of the user. The user may not use the work for commercial purposes.

Wageningen Economic Research accepts no liability for any damage resulting from the use of the results of this study or the application of the advice contained in it.

Wageningen Economic Research is ISO 9001:2015 certified.

Wageningen Economic Research Report 2021-062 | Project code 2282100418

Cover photo: Shutterstock 


\section{Contents}

$\begin{array}{ll}\text { Preface } & 5\end{array}$

$\begin{array}{ll}\text { Summary } & 6\end{array}$

S.1 Main research question $\quad 6$

$\begin{array}{lll}\text { S.2 Key Findings } & 6\end{array}$

S.3 Methodology 16

$\begin{array}{lll}1.1 & \text { Reduced demand for potatoes due to Covid-19 } & 7\end{array}$

1.2 Have CAP and Covid-19 policies distorted the market? $\quad 8$

$\begin{array}{lll}1.3 & \text { Study Set-up } & 8\end{array}$

$2 \quad$ Increasing potato and FPP production 9

2.1 Potato production increased $\quad 9$

2.2 Processing industry: production of frozen potato products (FPP) 11

$\begin{array}{ll}2.3 \text { Contracts and spot market } & 12\end{array}$

2.4 Summary 14

$3 \quad$ No clear influence of CAP support on potato and FPP prices $\quad 15$

3.1 How does CAP affect potato production and potato prices?

3.2 CAP support does not influence ware potato production or prices $\quad 15$

3.2.1 CAP has never been coupled to ware potato production 15

3.2.2 CAP support has never influenced ware potato prices in the EU 18

$\begin{array}{lll}3.3 & \text { Summary and conclusions } & 20\end{array}$

$4 \quad$ No influence of Covid-19 support on potato prices $\quad 21$

4.1 Large potato stocks at the moment of the first lockdown 21

4.2 Governmental measures and support per member state differ $\quad 22$

4.3 Effects of Covid-19 measures on the market situation and potato prices 24

$\begin{array}{lll}4.4 & \text { Summary and conclusions } & 27\end{array}$

$\begin{array}{llr}5 & \text { Covid-19 affects FPP export prices } & 28\end{array}$

5.1 No effect of CAP and Covid-19 on potato prices and FPP prices 29

5.2 Differences in intra-EU and extra-EU export prices 29

5.3 No significant influence of Covid-19 on FPP price difference 31

$\begin{array}{lll}5.4 & \text { Summary and conclusions } & 37\end{array}$

$\begin{array}{llr}6 & \text { Conclusions } & 38\end{array}$

$\begin{array}{ll}\text { References and websites } & 40\end{array}$ 



\section{Preface}

The sales and production of frozen potato products are closely connected to ware potato production. In this regard the impact of government support on potato production and the frozen potato product market and prices is an interesting research topic. This study was initiated by and carried out at the request of the European Potato Processors Association (EUPPA). Wageningen Economic Research thanks EUPPA for the trust placed in carrying out this research. We like to thank EUPPA and especially the EUPPA secretariat for the support, information, organising meetings and pleasant cooperation during the project. We also like to thank the EUPPA trade committee for their comments on draft reports.

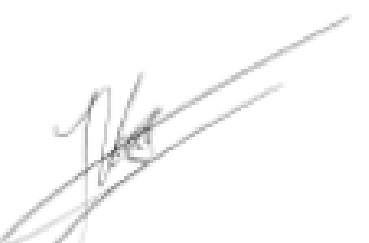

Prof.dr.ir. J.G.A.J. (Jack) van der Vorst Managing Director Social Sciences Group (SSG) Wageningen University \& Research

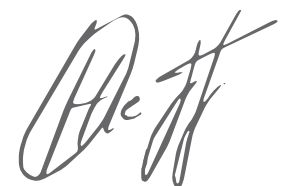

Ir. O. (Olaf) Hietbrink

Business Unit Manager Wageningen Economic Research Wageningen University \& Research 


\section{Summary}

\section{S.1 Main research question}

The main question of this research is what the impact has been of government support by the EU Common Agricultural Policy (CAP) and Covid-19 support measures by national governments to producers of frozen potato products (FPP) in Belgium, France, Germany and the Netherlands on the price of processing potatoes and on the export prices of frozen potato products (FPP).

\section{S.2 Key Findings}

CAP has evolved from a general production support system for agricultural production in the EU after World War II to a set of regulations for sustainable, climate- and environment-friendly agriculture and a liveable countryside throughout Europe. Currently, for potatoes almost all support is de-coupled from production. The ware and seed potato sectors have never been supported, neither the area nor the price. Ware potato itself has never been coupled to CAP support, because this crop has never been included in the Common Market Organisation of the EU.

The Covid-19 outbreak seriously disrupted the sale of FPP through a collapse in demand for potatoes, resulting in a substantial drop in potato prices. Only the governments in two main processing countries, i.e., Belgium and the Netherlands, took specific measures to support affected growers, while the governments in the countries with the largest potato production (Germany, France) did not take support measures for potato farmers. The governmental Covid-19 support for potato growers compensated only a part of the growers potato production costs and covered a limited part of the total potato market (only free, non-contracted potatoes in storage). Because these regulations were announced afterwards, the direct effect of governmental support on market and price formation of potatoes was nil. This also means that the Covid-19 support did not have an effect on the raw material price of FPP producers and FPP production costs.

Processors were excluded from the temporary government Covid-19 support on potatoes. Next to this, due to their contractual obligations they were dependent on purchasing more expensive contract potatoes and hardly benefited from the lower spot market prices of free potatoes. Processors were able to use general Covid-19 support measures (like tax measures) to compensate for the loss of turnover and part of labour costs, but it is not clear to what extent the potato industry made use of this.

Extra-EU FPP export prices in the four main potato producing countries (Belgium, France, Germany, the Netherlands) were on average lower than intra-EU FPP export prices. Both the level of the intra-EU and extra-EU export prices and the difference between them differed between the countries. Belgium, which produces mainly FPP for the retail market, had the lowest prices while Dutch potato processors produced more expensive FPP for the out-of-home market. Observed price differences between home and export market could not be linked to any kind of public support, neither in the short term (Covid19 support), nor in the medium term (CAP).

\section{S.3 Methodology}

The results were obtained through quantitative and qualitative analysis like desk research (literature, internet), descriptive and statistical analysis of prices, and regression-analysis. Data sources used in the statistical analyses included Northwest European Potato Growers (NEPG), Eurostat, EEX, and Comext. This data was supplemented with information from members of the European Potato Processors' Association and from meetings to discuss results. 


\section{Introduction}

\subsection{Reduced demand for potatoes due to Covid-19}

The Covid-19 crisis resulted in a substantial drop in demand for potatoes in the EU with, consequentially, a decline in potato prices and changes in intra-EU and extra-EU trade flows. Just like in case of ornamentals, potatoes seem to be more affected than other agricultural crops such as wheat, cereals, oilseeds and sugar beet (Jongeneel et al., 2021). Whereas intra-EU exports declined due to the Covid-19-related decline in demand, these European sales were partly offset by higher frozen potatoes product (FPP) exports to African and other non-EU countries. Some EU countries (Belgium, the Netherlands) introduced specific policy interventions to support affected potato growers, while other countries (Germany, France) did not. The question arose if these observed price and volume changes may have been due to such policy interventions.

To clarify these issues, the European Potato Processors' Association commissioned this study to Wageningen University and Research Centre. In addition to the assessment of the potential impact of Covid-19 support measures, they also requested an assessment of the potential impacts of the EU's Common Agricultural Policy (CAP) on potato production and its derived frozen products into the research questions.

The focus of this study is on frozen potato products (FPP) and the raw material (ware potatoes) used for FPP production. The study excludes other potato types than potatoes for FPP production, such as starch potatoes, potatoes used for fresh consumption (table potatoes) and seed potatoes. Special attention is paid to price disruptions, since price is a key variable in explaining competitiveness and level playing field issues. Figure 1.1 provides a schematic overview of prices relevant in the FPP sector, including farm-gate prices, FPP selling prices, both for the home market as well as export markets.

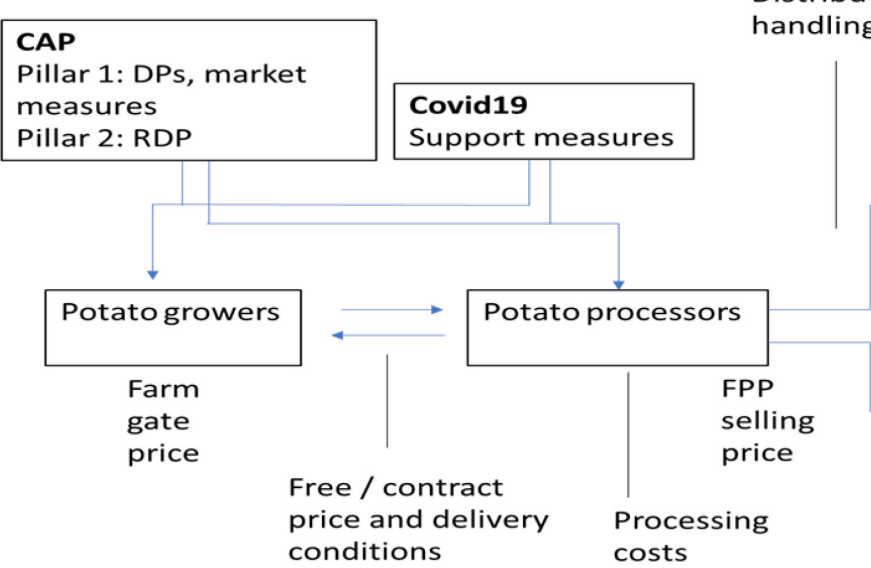

Figure 1.1 Price linkages and potential policy impact pathways

Although this study covers the EU, its main focus is on four EU Member States that dominate the FPP production and trade, notably France, Belgium, the Netherlands and Germany. Almost 50\% of the total EU-28 potato production is produced in these four countries (EU, 2019). 


\subsection{Have CAP and Covid-19 policies distorted the market?}

The main research question of this research is whether the CAP and Covid-19 policies have affected the FPP sector and created market distortions. To answer this question the following five subquestions are addressed:

1. How have potato cultivation areas and FPP production in the four major FPP-producing MSs of the EU developed in the last decade and which effect had Covid-19 on area and production?

2. Why does the EU support farms through CAP and how is the CAP support for arable farms organised? How does this influence profitability of ware potato growing and the potato market in the EU in general and in the four MSs specifically?

3. Which measures have been taken by the governments of the four MSs to support potato farmers and the processing industry to overcome the Covid-19 crisis? How have these measures influenced the market situation of ware potatoes including the raw material price for the industry and the FPP volumes (stocks) and prices?

4. Is there price differentiation between intra- en extra-EU FPP prices of European origin, discerned for the four MSs? If so, how can price differences be explained?

5. Does governmental support through CAP or Covid-19 measures lead to (more or less) price discrimination between intra- en extra-EU FPP prices of European origin?

\subsection{Study Set-up}

This study has been organised as follows. The next chapter (Chapter 2) provides a description of the evolution of the FPP sector in the four major FPP-producing countries, both at the level of primary production as well as at the level of the processing industry, and the impact of Covid-19. Materials and methods are presented at the beginning of each chapter. Chapter 3 discusses the evolution of the CAP and how it has affected the FPP sector. Chapter 4 focuses on the Covid-19 support measures in the four major FPP-producing Member States and how they affected the FPP sector. In Chapter 5, a further assessment of prices is made and reasons and explanations which could explain observed differences in import, export and local prices. Chapter 6 closes the study by summarising the main conclusions. 


\section{Increasing potato and FPP production}

\subsection{Potato production increased}

The central question in this chapter is: how have potato cultivation areas and FPP production in the four major FPP-producing Member States (MSs) of the EU developed in the last decade and which effect did Covid-19 have on area and production? This chapter is based on a descriptive analysis of time series of Eurostat data, data presented by the Northwest European Potato Growers (NEPG) and information from EUPPA.

FPP are made from ware potatoes. Ware potatoes include fresh or table potatoes and industrial potatoes for processing into frozen potato products (FPP), chilled processed products and crisps. Ware potatoes do not include seed potatoes or starch potatoes. Data on the share of ware potatoes at farm level going to FPP are not available. Therefore, we describe the development of the ware potato sector as a whole.

This chapter focuses on the development of ware potato acreage, ware potato production and FPP production in Belgium, France, Germany and the Netherlands. The four Member States of the EU are among the largest producers of ware potatoes in Northwestern Europe. Almost 50\% of the total EU-28 potato production (52 million tonnes in 2018; including seed potatoes) is produced in these four countries (EU, 2019). Germany (17.2\%) and France (15.2\%) are the largest producers, followed by the Netherlands (11.6\%) and Belgium (5.9\%). The production in the Netherlands also contains a significant proportion of seed potatoes.

Because potatoes in Eurostat statistics include seed and starch potatoes, figures were sought that better reflect the production of ware potatoes, excluding seed. The Northwest European Potato Growers (NEPG) collects and presents ware potato figures annually (Figure 2.1).

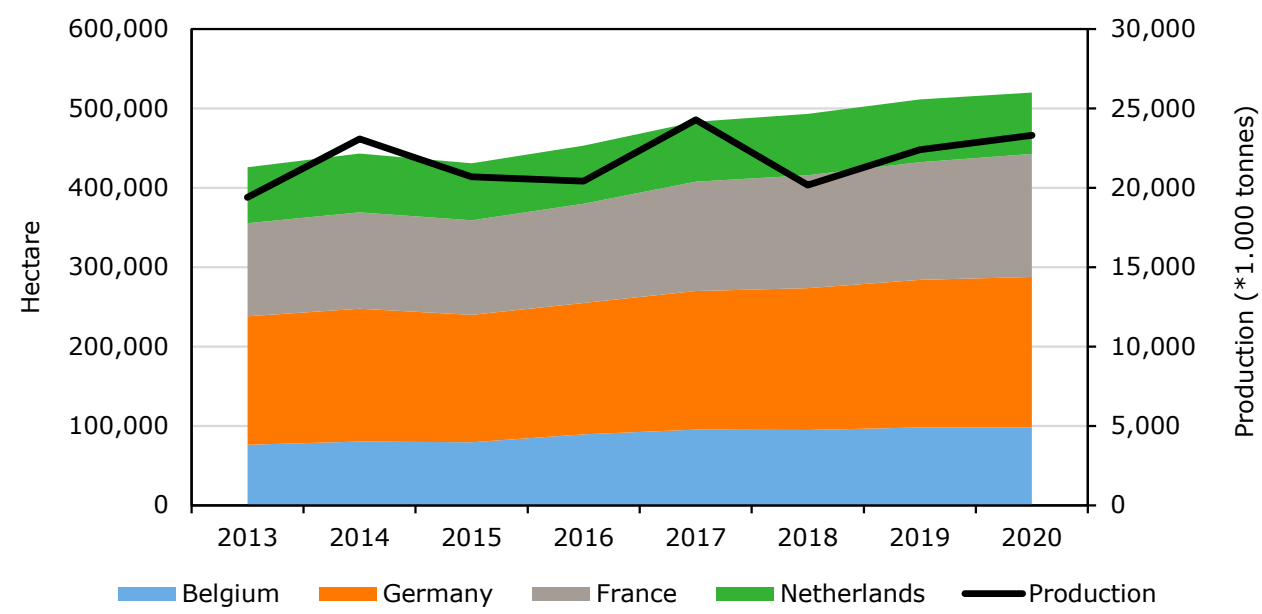

Figure 2.1 Development of ware potato acreage (ha) and production in Belgium, France, Germany and the Netherlands

The figure shows that the total ware potato acreage of the four Member States together expanded steadily from 430,000 ha in 2013 to 520,000 ha in 2020, a growth of $22 \%$. Total production followed this trend $(+20 \%)$. Germany has the largest acreage of ware potatoes (with a share of $37 \%$ of the total area in these four MSs), followed by France (30\%), Belgium (19\%) and the Netherlands (15\%). This distribution almost corresponds with the production share. 
Figure 2.2 shows that the acreage ware potatoes for each of the four MSs increased from 2013 onwards. The acreage expanded in France and Germany in particular, while the expansion stagnated in Belgium and the Netherlands in 2020. It is unlikely that this stagnation in 2020 was the result of the Covid-19 crisis, because this crisis started at a time potatoes were already planted (March-April 2020).

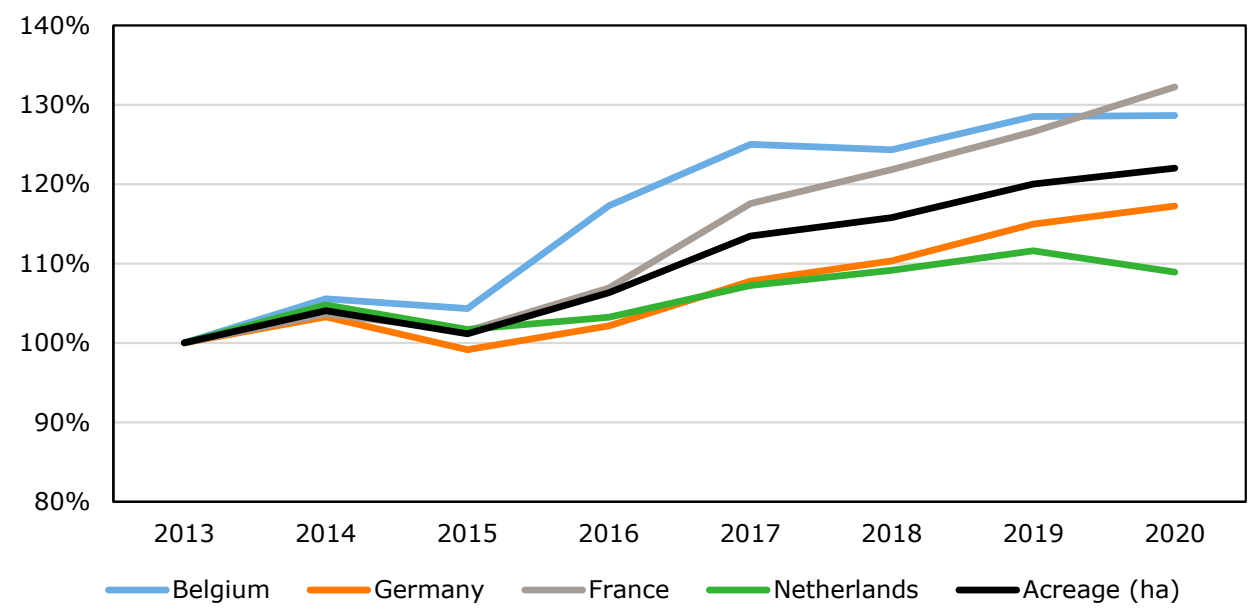

Figure 2.2 Relative development of acreage ware potato per Member State (2013 = 100\%) Source: NEPG, analysis Wageningen Economic Research.

Yield and production

In 2013, the potato yield in the four MSs amounted to an average of 45.5 tonnes per hectare, while in 2020 this amounted 44.8 tonnes per hectare. Figure 2.3 shows that the average yields have been considerably lower in recent years, mainly due to drought in 2018 and 2020. Compared to the Eurostat hectare yields (average seed, starch and ware potatoes), the NEPG potato yields of only ware potatoes are higher but the yield patterns are comparable over the years. Total production (see Figure 2.1) increased mainly due to the acreage expansion, which partly compensated for the lower yields due to drought in 2018 and 2020.

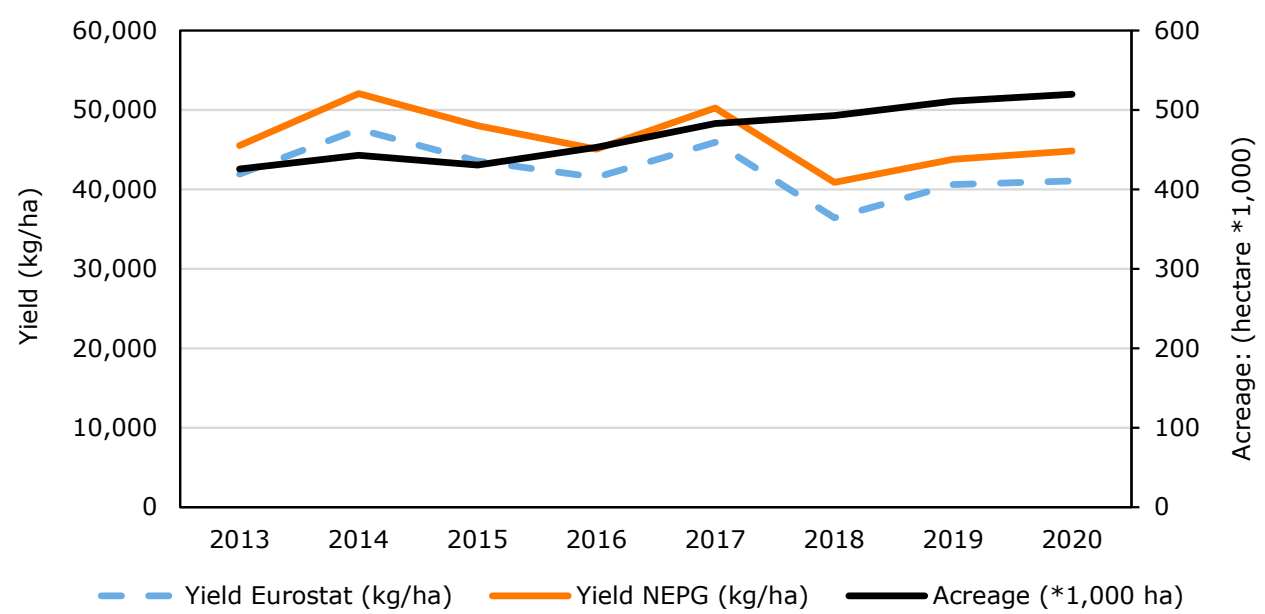

Figure 2.3 Development of acreage and yield of ware potatoes in 4 MSs Source: NEPG, analysis Wageningen Economic Research. 


\subsection{Processing industry: production of frozen potato products (FPP)}

This section focuses on the use of raw material and production of FPP by the four countries. The availability of detailed data on the potato processing industry per country is limited; most countries () only report use of raw material (potatoes) and production of finished products per year; only the Netherlands reports monthly FPP productions. Germany reports per season and Belgium and France per year.

Ware potatoes are sold through various channels: the largest part is processed by potato processing companies into frozen and chilled potato products. A relatively small part $(10 \%)$ is delivered as fresh table potatoes. Another small part (mainly by-product) is sold as animal feed or as raw material for bio-energy production (Janssens et al., 2020).

Table 2.1 gives an overview of the volumes of potatoes processed into FPP and some other products in 2019. It is estimated that the four countries together in 2019 processed 11.3 million tonnes of potatoes into 6.3 million tonnes of potato products of which 5 million tonnes FPP.

Table 2.1 Potatoes processed (million tonnes), 2019

\begin{tabular}{|c|c|c|c|c|c|}
\hline & Belgium & France & Germany & The & Total 4 Member \\
\hline & & & (only frozen) & Netherlands & States \\
\hline Raw material: potatoes & 5.3 & 1.0 & 1.1 & 3.9 & 11.3 \\
\hline - Of which frozen & 2.23 & 0.48 & 0.54 & 1.75 & 5 \\
\hline
\end{tabular}

Sources: EUPPA.

Belgium is the largest FPP producer, followed by the Netherlands. These both countries produce more than half of the total European frozen potato products (CBS, 2016). In these two countries, the potato processing industry has grown significantly in the past decade.

In Belgium, the amount of processed potatoes increased from 3.3 million tonnes in 2010, to 5.3 million tonnes in 2019 ( $+38 \%$ ) (source: Belgapom). In the Covid-19 year 2020, this amount fell to 5.1 million tonnes, a decrease of $4 \%$ compared to the previous year. Belgian processors mainly serve the retail markets. In the Netherlands, the growth of the processing industry was from 3.4 million tonnes processed potatoes in 2010 to 3.9 million tonnes in $2019(+15 \%)$. In 2020, the volume of potatoes processed by Dutch processors fell to 3.4 million tonnes ( $-13 \%$ compared to 2019 ). The most important market for Dutch FPP processors is the out-of-home segment. In Germany, the amount of processed potatoes has remained fairly stable at 3.6 million tonnes per year since 2011 , which is processed into various products (e.g. dried, chips, salads, fries); 1.1 million tonnes of these potatoes are processed yearly into 0,54 million tonnes of frozen fries. The French FPP production is estimated at 0.48 million tonne of frozen product for which 1 million tonnes of potatoes are needed. There is only one major processor in France who mainly serves the local quick service restaurant market.

Due to their extensive raw material requirements, Belgian and Dutch processors import potatoes from neighbouring countries. Germany exports between 1.5 and 1.75 million tonnes of ware potatoes for processing to Belgium and the Netherlands and France exports 1.7 million tonnes potatoes to these countries.

Figure 2.4 shows the impact of the Covid-19 crisis on the annual FPP production. In all four countries the FPP production in the Covid-19 year (2020) is lower than in the previous pre-Covid-19 year (2019). The impact was particularly great in the countries that produce FPP for the out-of-home market (The Netherlands, France and Germany) with a production decline of about $10 \%$ or more. In Belgium, which mainly produces FPP for the retail market, the drop in production was limited to $1.4 \%$. 


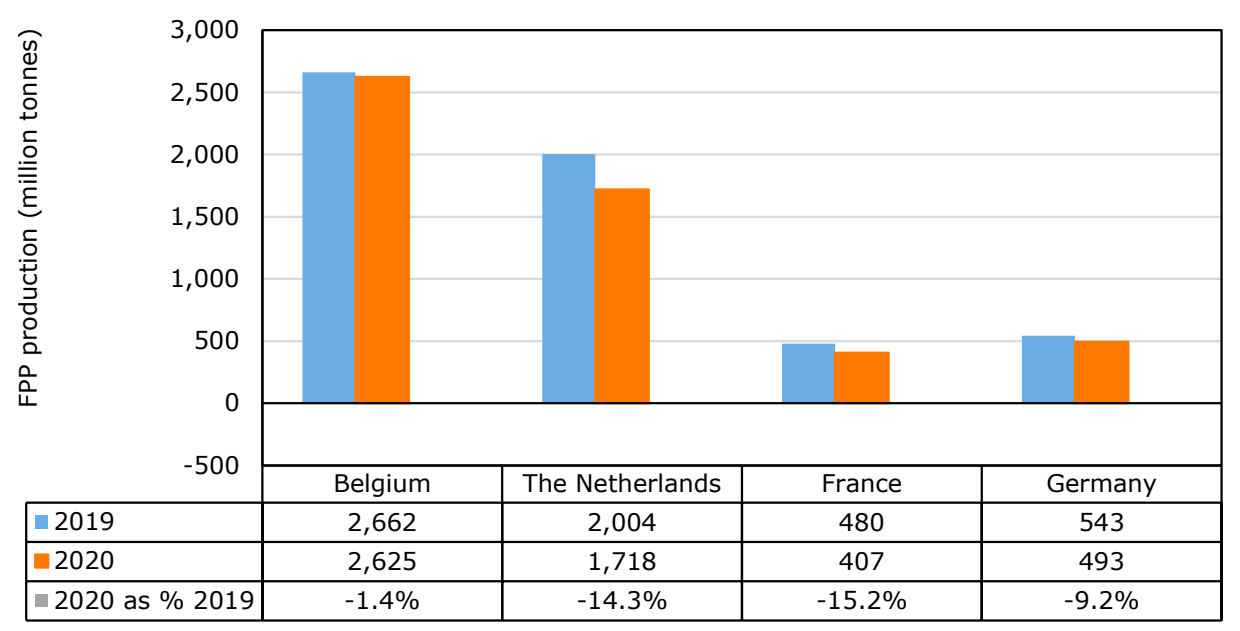

Figure 2.4 FPP production (million tonnes) in 2019 (pre Covid-19 year) and 2020 (Covid-19 year) in four Member States

Source: EUPPA, analysis Wageningen Economic Research.

\subsection{Contracts and spot market}

European potato processors collect raw material (potatoes) from potato growers and traders. Contracts are used to ensure the sale of FPP and to establish that the purchase of potatoes (volume) and/or to avoid the risk of purchasing potatoes on the spot market with volatile prices. Growers, traders, and processors market their potatoes during both the harvest season (August-October) and the storage season (November-July) through different mechanisms:

- Tonnes (or volume) and cultivation contracts

This can happen either in with a fixed quantity of potatoes with provisions regarding variety, quantity, quality, time of delivery and price - tonnes contracts - are determined for tonnes contracts or on the yield of one or more lots of potatoes of a specific variety are sold on the basis of a specific cultivation method to a buyer at a certain price (fixed price) - cultivation contracts. In both cases, these contracts are concluded before the start of the growing season.

- Hectare contracts

In such contracts, a fixed volume per hectare from a specified number of hectares of potatoes is specified and a fixed price is set. If the hectare yield exceeds the agreed volume per hectare, the remaining potatoes or surplus potatoes are usually delivered at the same time at the day price of the spot market.

- Pool contracts

A pool is usually set up for bundling larger volumes of product of uniform quality or a variety. The principle of 'price pooling' means that a group of entrepreneurs purchases and/or sells together and ultimately all pay or receive the same average purchase or sales price over the season, regardless of when the individual entrepreneur delivers his product to the pool. In practice, there are different variants of pool contracts. For example: pool with pre-sale, pool without pre-sale, and pool with a minimum price.

- Spot market

On this spot or free market, transactions can be concluded within a season with an immediate delivery (within 10 days) or with a later delivery (weeks or months later). These deals are made during the harvest and storage season when yields and quality are known.

In practice, various types of contracts are used (Janssens et al., 2011) but the contracted volume does not give transparency on the raw material price of these potatoes. A contract can lead to an obligation to deliver at the day price or at a fixed price. In addition to 1-year agreements, multi-year contracts ( 2 or 3 year) between growers and processors are now an option. In case of hectare contracts, the question is whether surplus potatoes are included or not. Or in the case of potatoes within pool contracts: are these potatoes qualified as contracted potatoes or not? In the case of 
hectare contracts, part of the contract volume is settled at a fixed price and the rest at the daily rate. Even the volume that is settled at a fixed price can vary from year to year and from processor to processor. To determine the purchase price of processing potatoes, it is important to know the distribution between the contracted and free potatoes. Table 2.2 provides an estimate of the distribution between the contracted tonnes and free potatoes used by processors; figures on the distribution per year are not available. This is an overall average estimation. Figures for a specific processor can differ significantly.

Table 2.2 Overview of volume shares contracted and free processing potatoes and contract type per country

\begin{tabular}{lcccc} 
Contracted & Belgium & France & Germany & \\
& $65 \%(60 \%-70 \%)$ & n.a. & $75 \%$ & $\begin{array}{c}\text { Netherlands } \\
\text { (including surplus } \\
\text { potatoes) }\end{array}$ \\
\hline Contract type & $>95 \%$ tonnes-contract & n.a & tonnes-contract & Mainly ha-contract \\
\hline Free & $35 \%(30 \%-40 \%)$ & n.a & $25 \%$ & $20 \%$ \\
\hline
\end{tabular}

Source: EUPPA.

Free potatoes are settled at the day price (spot market) at the time of delivery. Contracts are mostly agreed at the start of the season. In case of contracted potatoes the price depends on the type of contract. In case of price contracts agreed prices at the time of contracting apply; for volume contracts and pooling contracts day prices apply. Hectare contracts consist of a fixed part of the volume at a fixed price and the remaining volume at a daily price; the size of the remaining volume depends on the hectare of yield.

\section{Example hectare contract}

Table 2.3 shows an example to illustrate the effect of a hectare contract on the farmers potato price. In the case of a hectare contract, a number of hectares are contracted, whereby a fixed volume to be delivered per hectare is agreed at an agreed price. If the harvest per hectare exceeds the specified quantity per ha, the extra potatoes are sold as co-delivery potatoes. If the harvest is less than the agreed quantity, the grower must ensure that the contract obligations are met by buying potatoes elsewhere. In case of a 35-tonnes hectare contract at a fixed price and a yield of 50 tonnes per hectare, 35 tonnes is paid at the fixed price and 15 tonne at day price (spot market). In the case of a 25-tonnes hectare contract, 25 tonnes will be paid at the fixed price and the other half at the day rate. in the latter case, the grower on average receives a lower price per kg delivered. If the day price were above the fixed price, the grower would receive more in the 25 -tonnes case compared to the 35-tonnes contract.

Table 2.3 Example to illustrate two variants of a hectare contract

\begin{tabular}{lrr} 
& 35 tonnes & 25 tonnes \\
Agreed volume at fixed price of 15 eurocents per kg & 35 & 25 \\
\hline Surplus potatoes at spot market price of 10 eurocents per kg & 15 & 25 \\
\hline Average price per $\mathrm{kg}$ & 13.5 & 12.5 \\
\hline
\end{tabular}

In case spot market prices are higher (for example 20 eurocents per $\mathrm{kg}$ ) the average price of a 35-tonnes contract is 16.5 eurocents per $\mathrm{kg}$ and of a 25 -tonnes contract 17.5 eurocents per $\mathrm{kg}$.

Processors will at all times first fulfil their contractual obligations towards their clients and, as a consequence, towards the farmers with delivery contracts. The processors buy additional potatoes on the spot market to complete the volumes required. This strategy makes them flexible to adapt to higher or lower FPP demands from clients than expected beforehand. Besides the exact volumes of FPP demanded, also the quality of the (contracted) potatoes can have an impact on the activities of companies on the spot market. 


\subsection{Summary}

Main findings in this chapter:

- Within the group of four countries studied, Germany and France produce the largest volumes of ware potatoes yearly. The total potato acreage in Belgium, France, Germany and the Netherlands has increased in recent years.

- Potato production steadily increased from 2013 to 2020, although drought in 2018 and 2020 resulted in lower production in these years.

- Covid-19 crisis did not have an effect on the development of the planted potato area in 2020 in the four countries, because most potatoes were already planted when the crisis started (March-April 2020).

- Belgium is the largest FPP producer, followed by the Netherlands. These countries also have the largest potato processing industry. Both countries import a substantial quantity of potatoes from Germany, France, and other neighbouring countries to comply with demand.

- Due to the Covid-19 crisis, the FPP production decreased in 2020 in all four countries, especially countries serving the out of home market.

- A significant proportion ( $>65 \%$ ) of the potatoes for processing are contracted, based on various contract types. 


\section{No clear influence of CAP support on potato and FPP prices}

\subsection{How does CAP affect potato production and potato prices?}

The goal of this chapter is to quantitatively and qualitatively investigate whether there is EU support for potato growers from the Common Agricultural Policy (CAP) and if and how CAP support influences the final FPP price in a significant way. EUPPA wants insight into the CAP support provided to ware potato growers in the EU and to what extent this support affects the potato market, FPP markets and FPP trade. They have asked to quantitatively and qualitatively assess the support provided by the EU for potato growers and the way this impacts on the final FPP prices (fact-finding). The research questions addressed in this chapter are:

1. Why does the EU support farms through CAP and how is the CAP support for arable farms organised? How does this influence profitability of ware potato growing and, indirectly, the potato and FPP markets in the EU in general and in the four MSs specifically?

2. Does governmental support through CAP affect EU potato production and, indirectly, EU FPPproduction (in a positive way)?

\subsection{CAP support does not influence ware potato production or prices}

This section answers the following questions:

- Why does the EU support farms through CAP and how is the CAP support for arable farms organised? (3.2.1)

- How does this influence profitability of ware potato growing and the potato market in the EU in general and in the four MSs specifically? (3.2.2)

\subsubsection{CAP has never been coupled to ware potato production}

CAP started in 1957, aiming to provide farmers with a reasonable income and consumers with sufficient food. In the last decades CAP has been given a broader range of goals, like protection of nature and environment, climate change mitigation and livelihood of the countryside. There is a development from food and income provision to payments to farmers for societal services (website Toekomst GLB, visited 12-03-2021). The developments in the way CAP has been organised, are summarised in Figure 3.1.

In the first years of $\mathrm{CAP}^{1}{ }^{1}$ the European farmers received guaranteed minimum prices for a number of agricultural products like milk, beef, cereals, rape seed, peas and starch potatoes. However, ware and seed potatoes have never been part of the regulations in this common market, i.e. these crops have never been included in the list of products under the Common Market Organisation (CMO) in the Treaty on the European Union. ${ }^{2}$ On the contrary, (sweet) potatoes are explicitly excluded from the

\footnotetext{
1 In that period, the EU consisted only of six member states: France, Italy, (Western) Germany, Belgium, Luxembourg and the Netherlands, which gradually increased to a number of 27 member states in both western and eastern Europe, but since Brexit (1 January 2021) without the United Kingdom. See this website for more details about the development of the EU.

2 The reason to also mention seed potatoes here, is that support to seed potato production could lead to price changes of this crop. That would then influence the cost price and margin of ware potatoes, being one of the (major) inputs in ware potato cultivation. However, the reasoning in this chapter for ware potato is also valid for seed potato. As a consequence, the absence of support of ware potato both in the past and in the future also includes seed potato.
} 
products supported (See e.g. EU, 2013). ${ }^{3}$ Ware potatoes have always been a so-called 'free' product (EU, 2013; Europatat, 2016). ${ }^{4}$

'Potatoes are one of the few agricultural products for which there is no Common Market Organisation (CMO). The potato sector has often been referred to as a symbol for autoregulation of agri-food schemes by national and international specialists. Since 2008, as a part of simplification rules of the CAP, all the potato areas in the EU can be potentially eligible to receive direct payments.' (cited from Europatat, 2016)

The EU price policy appeared to be very successful. It led to high surpluses of the products that were supported. This cost the EU a lot of money, since they had to buy these surpluses from the farmers and get rid of them. A first CAP-reform became necessary. From 1992 onwards, price support through CAP was abolished and replaced by direct support. This direct support was still coupled to the amount of products delivered.

A new reform, 'Agenda 2000', led to two CAP pillars. Different measures for rural development were introduced, e.g. the option to establish producer organisations (POs) and support for young farmers. During this reform, the market support for cereals, beef, milk and dairy products was step-by-step reduced. At the same time, direct coupled payments to farmers were increased. In a mid-term CAP review in 2003, the EU decided to de-couple subsidies to certain crops from their yields. That became the dominant policy in the following years. The way in which different MSs implemented this policy differed. The Netherlands decided to base the payment level on 'historic payments', i.e. the support in former years. In 2012, the last sectors in the Netherlands, among which the starch potato sector, were de-coupled. In other MSs, immediately a flat rate per ha was introduced, sometimes an individual rate combined with a regional component, e.g. in Germany (see e.g. Janssens and Prins, 2004, Table 3.1). Today, all MSs have a MS or regional specific flat rate for all hectares in all sectors, independently of the crops grown. ${ }^{5}$ In e.g. the Netherlands, all differences between farms, regions and sectors have been abolished, meaning that the same rate is paid per eligible ha of land.

Table 3.1 Overview of system, decoupling and date effective

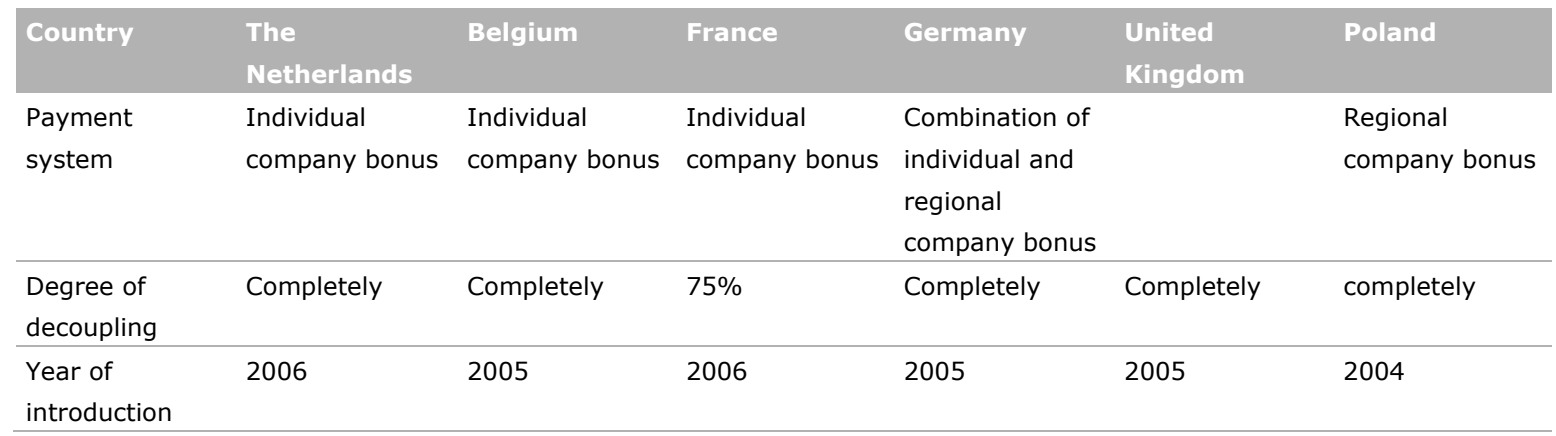

In 2003, cross compliance conditions were introduced, which oblige farmers to fulfil certain conditions in the fields of environment, food safety and animal welfare to receive payments. Part of this framework are the Good Agricultural and Environmental Conditions (GAECs), which are meant to ensure that all agricultural land, especially land which is no longer used for production purposes, is maintained in good agricultural and environmental conditions. The cross compliance conditions did not make a difference between crops and had therefore no supporting effect on potatoes. This decision led to 'modulation', i.e. that from 2005 onwards annually part of the single payments were transferred to the rural development fund. This modulation was raised to $10 \%$ from 2012 onwards, which was decided in the Health Check Agreement of 2008. The rural development fund was created to tackle

3 Seed potatoes are not mentioned at all in this list.

4 'Free' in this context means that there is no Common Market Organisation for this product, ware potato.

5 Including set-aside hectares. 
new challenges: biodiversity, climate change, water management and renewable energy and innovation on all of these challenges, and structural improvement of the dairy sector. At the same time, the regulation on income support was adapted. It became possible to spend additional budgets for special goals, like quality agriculture, economically or ecologically vulnerable sectors or risk insurance.

From 2015 onwards, the EU has a new system of payment rights: a flat rate per ha. In this system, there are no differences between potatoes and other crops and the competitive power of potatoes is therefore not affected. From 2019, all farmers in the Netherlands have received the same payment per ha. In other MSs, there have often been different regions with regionally defined flat rate payments (e.g. France, Belgium and Germany). An important goal is 'greening', which should lead to a more sustainable agriculture and protection of biodiversity. Arable farmers receive a greening payment, which is $30 \%$ of the total flat rate, but only if they comply with the greening conditions. This system should have ended in 2021 but is prolonged until 2023.

In summary, the CAP post-2020 reform is one in a row of reforms. While focusing on the Treaty objectives, the CAP since its birth in the 1960s has continually evolved to better address existing and upcoming challenges and to account for shifts in the local and global contexts. Though farm income concerns are still important, the CAP covers a much wider range of aspects. It has also increased its emphasis on the environment, climate and the wider rural context in which farming operates. Policy challenges may result from changing contexts, such as the observed increased price volatility and instability in weather conditions due to climate change. Moreover, there have been changes with respect to the interactions with regard to the wider economy, for example due to biofuels (intensifying agriculture's linkage to energy markets) and innovations in the bio economy. Milestones were the transition from a classical price support system (including associated border measures) to a system of direct support (initiated with the 1992 Reform), the introduction of a second pillar on Rural Development Programs (Agenda 2000), the decoupling of direct payments from production (initiated with the 2003 reform) (cited from Jongeneel (2018)).

The new CAP post 2020 proposals imply a rebalancing of the responsibility between the EU and Member States (MS), allowing more freedom with respect to measure implementation and design to MSs (subsidiarity), a shift in focus from compliance to performance, a fairer distribution of direct payments (DPs), a strengthening of the focus on innovation and enhancing ambitions with respect to the environment and climate by again revising the green architecture (cited from Jongeneel, 2018).

The expected post 2021 CAP changes are:

- The payments per ha in Western European MSs will decrease due to lower budgets (as a consequence of Brexit) and internal levelling (i.e. higher flat rates for Eastern European MSs at the cost of Western European rates);

- The greening conditions will become part of the so-called conditionality, meaning that compliance is obligatory to receive a flat rate at all, i.e. not only the greening payment.

- At the same time, MSs become obliged to offer eco-schemes, i.e. that farmers are paid to take additional measures for mainly climate change mitigation and biodiversity restoration. Farmers will not be obliged to adopt these packages, but the flat rate will decrease due to the budgets in the first pillar that will be kept apart for paying the compensation for adoption of the eco-packages.

- The launch of a Green Deal and a so-called 'Farm-to-Fork Strategy' could affect the use of fertilisers and pesticides, although it is still not clear how strong their influence will be. Such regulations could have an effect on the relative position of different crops, but that then will come forth from environmental considerations rather than from farm, crop or product support.

All these developments will not lead to extra support for potatoes. In fact, an increased level of conditionality could imply additional requirements for potato growing (Berkhout et al., 2021). Further reduction of pesticide and fertiliser use could have relatively high impacts on potato growing compared to other crops, due to the intensive cultivation methods including high inputs. 


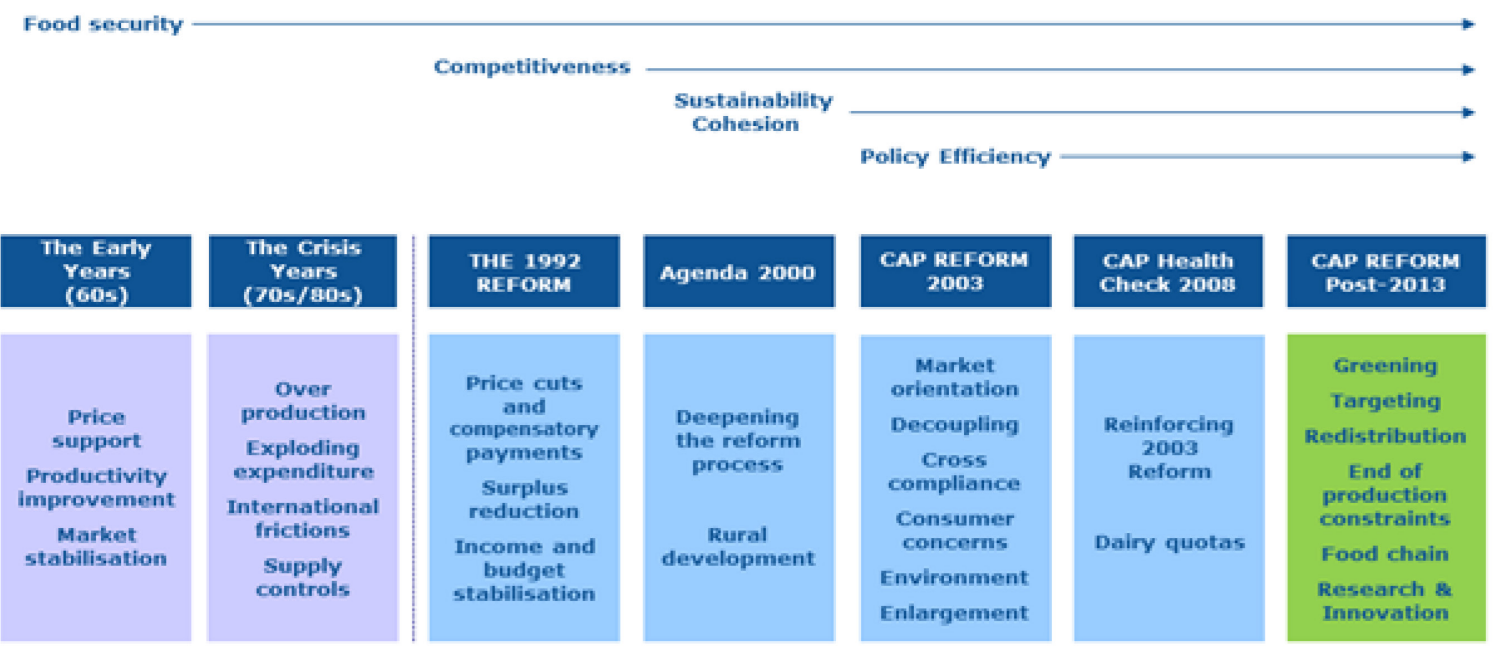

Figure 3.1 Historical development of the Common Agricultural Policy (from Jongeneel, 2018)

Summarising, the answer on the question 'Why does the EU support farms through CAP and how is the CAP-support for arable farms organised?' is:

- Why? Originally CAP was designed to overcome a lack of food after World War II and still food security is one of the goals. Other goals are now e.g. making European agriculture more sustainable, and improving the countryside and rural communities.

- How? CAP started with price support for a number of products, like milk, beef, cereals, peas, rapeseed, and starch potatoes. Ware and seed potatoes however, have never received price support. Over time, price support was replaced by payments per ha of supported crop, neither including ware or seed potatoes. Finally, a fully de-coupled support or flat rate was introduced for each ha of land that is managed according cross compliance and GAECs (Good Agricultural and Environmental Practices), which is in fact a form of income support that is totally de-coupled from agricultural production. It is even possible to set aside agricultural land, as long as it is kept in a good condition.

\subsubsection{CAP support has never influenced ware potato prices in the EU}

The main question in this section is: How does CAP influence profitability of ware potato growing and the potato market in the EU in general and in the four MSs specifically?

The EU-ware potato market typically behaves as a demand-supply market. E.g., in the years 20162018 selling prices for potatoes fluctuated significantly over time and between countries, on both producer and consumer markets, which is partly due to strong annual fluctuations in production (De Cicco and Jeanty, 2019). There are also often differences in price development between the two markets for the same year and in the same Member State.

It could be argued that price or production support for common market products like cereals, rapeseed and starch potatoes could stimulate the cultivation of these crops at the cost of e.g. seed and ware potatoes. Such a shift could lead to relatively low areas and production levels of seed and ware potatoes and, consequently, to higher prices of such products. However, since 2015 the single payments in the EU to farmers have been fully de-coupled from production ${ }^{6}$ in the four MSs in our

\footnotetext{
6 The CAP-Reform of 2013 gave MSs the option to give coupled support to certain common market crops and products like sugar beet and beef (but certainly not for seed or ware potatoes). However, the four MSs in our study (France, Germany, Belgium and the Netherlands) did not adopt this option for any crop or product (Smit et al., 2017). E.g. in Poland, sugar beet production receives coupled support, which probably had led to an increase of the area of that crop there. However, the share of such a crop in the crop rotation of Polish arable farmers is still so small, that an influence on potato production and markets is not to be expected. Additionally, Poland is not a major player in FPP production.
} 
study and in a number of MSs even longer. A potential area or price effect of the CAP on seed and ware potatoes in the EU since then is highly unthinkable.

Another argument that could be used, is that a flat rate could trigger the buyers and processors of e.g. ware potatoes to more sharply negotiate with the farmers about the resource price. E.g. with a single payment of 400 euros per ha and a yield of 40 tonnes of ware potatoes per ha, FPP producers could state that CAP provides already a 'premium' of (400 euros/40,000 kg =) 1 euro per $100 \mathrm{~kg}$ and consequently keep that 'premium' in their pocket, i.e. leaving the farmer with a 1 euro lower selling price. However, the FPP-producers are not expected to do that, since they know that the European farmers have to deal with the strictest sustainability and food safety regulations ${ }^{7}$ in the world in return to the flat rate. This leads to relatively high production, storage and delivery costs at the farms. ${ }^{8}$ Besides, land prices in the ware potato growing regions in the four MSs studied are relatively high, up to more than 100,000 euros per ha in e.g. the province of Flevoland in the Netherlands. Concluding, the flat rate does not give the ware potato growers in the EU a competitive advantage compared to colleagues outside the EU, but merely a compensation of (a part of) the higher production costs within the EU, which originate from both compliance obligations to e.g. European sustainability (e.g. greening) and food safety regulations and higher capital costs (besides land, also machinery and labour have relatively high prices, especially in Western Europe). Selling prices of ware potatoes in the $\mathrm{EU}$, both the free market and the contract prices, generally reflect the balance or, in some years, imbalance between supply and demand of FPP and, consequently, of ware potatoes for FPPproduction. $^{9}$

A third argument could be that support of starch potatoes in the past (before the period of flat rates) has led to a relatively low share of seed and ware potatoes in certain regions, mainly regions that are now well-known for their large areas of starch potato. However, average margins for ware potato have always been higher than for starch potato, even with support for starch potatoes. Ware potato prices, at least the part that is dealt with in a free market, i.e. not being contracted beforehand, strongly fluctuate between years. Starch potato prices are much less volatile, the production being fully regulated in contracts between the processing industry and growers. ${ }^{10}$ Besides, regions with a large area of starch potatoes are mostly not suitable for ware potato growing, leading e.g. to a browncoloured skin and a less good quality and taste of ware potato, which is not a problem for the processor of starch. Starch potatoes cannot be used for the processing of FPP, which is the scope of this report.

Summarising the arguments raised and the counter facts listed, we conclude that:

- Seed and ware potatoes have never been part of the common market of the EU.

- It is very unlikely that seed and ware potato prices have been influenced by former price or production support for other crops like cereals, peas or starch potatoes. The flat rate system that is in use since 2015 , does not affect the relative profitability of the different crops that could be grown at arable farms in the four MSs studied.

\footnotetext{
7 Including a ban on chlorprofam, Reglone and Finale.

8 This is also true for the FPP industry, that has to deal with the strictest sustainability and food safety regulations in the world, and consequently with relatively high processing, storage and handling costs at their processing plants, storage halls and transportation facilities. E.g., the FPP-industry has paid for the costs of replacing IPC chlorprofam by alternative, more expensive germination inhibitors (Dodde, 2020). These costs were estimated to be 1 to 1.5 eurocents per $\mathrm{kg}$ (Dodde, 2019). Likewise, the costs of haulm killing in potatoes have increased due to a ban on herbicides as Reglone and Finale (Moggré et al., 2019). This ban makes an application of alternative haulm killers necessary in combination with mechanical killing, compared to a single chemical application in the past. The additional costs are at least 100 euros per ha (contractor costs of mechanical haulm killing, the extra costs of additional chemical haulm killer not included; KWIN, 2018). The FPP-industry will therefore not be able to compete on selling price, although a highly efficient production process can compensate for part of the higher 'compliance' costs. It would be more logical to assume that European FPP producers have to compete on food quality and safety, i.e. the best quality-price ratio which is not necessarily the lowest price possible.

9 Assuming that in general FPP processors require other ware potato varieties than other (types of) ware potato purposes, like fresh consumption, salads etc. This also implies that the market for FPP potatoes is different from the market for fresh potatoes and that these markets normally do not interact, except perhaps for a number of varieties that are suitable for both purposes.

${ }^{10}$ Besides the effect of these contracts on prices, it is not easy to start or to quit starch potato growing, since delivery rights are required to be able to deliver starch potatoes to the processor and, on the other hand, having such rights, the growers also have the obligation to deliver the amounts of starch potatoes in the contract to the processor.
} 
- It is also very unlikely that FPP-processors claim the flat rate paid for ware potato land for themselves, since the flat rate is a compensation for relatively high costs for sustainability (e.g. greening) and food safety regulations and higher capital costs in the EU. The contract negotiations and the free market prices reflect the balance between supply and demand, and the demand by the FPP-processors strongly depends on the demand for their products in the different markets. ${ }^{11}$

Possible indirect effects of CAP are not to be expected either. E.g., the regulation on Voluntary Coupled Support (VCS) does not apply on potato (Smit et al., 2017). Thus, extra potato production must not be expected from this regulation, perhaps even some decrease when other crops, like sugar beets, are stimulated by this support and lead to a better relative position compared to potatoes.

\subsection{Summary and conclusions}

The research questions in this chapter were:

1. Why does the EU support farms through CAP and how is the CAP support for arable farms organised? How does this influence profitability of ware potato growing and the potato market in the EU in general and in the four MSs specifically?

2. Does governmental support through CAP affect EU potato production (in a positive way)?

Our analysis shows that CAP has evolved from a general production support system for agricultural production in the EU after the World War II to a set of regulations for sustainable, climate- and environment-friendly agriculture and a liveable countryside throughout Europe. Currently, almost all support is de-coupled from production and ware (and also seed) potato has never been supported, nor the area nor the price. Ware (and seed) potato has never been included in the Common Market Organisation of the EU since the start of CAP with all the changes that have taken place.

\footnotetext{
${ }^{11}$ There has once be a minor type of support for temporary stocking, including potatoes. This is the only exception about support of potatoes, but without significant price effect.
} 


\section{$4 \quad$ No influence of Covid-19 support on potato prices}

The impact of the Covid-19 pandemic for the potato processing industry became fully clear in the spring of 2020. Worldwide lockdowns of restaurants and fast food chains in various countries meant that out-of-home consumption stagnated almost completely. As a result, the sales and consequently production of FPP stagnated and also part of the processing potatoes that were still in stock could no longer be processed. The situation had major consequences for potato growers, especially those growers who still had potatoes in stock, and the potato processing industry. Farmers had to find alternatives for the sale of the ware potatoes for processing in stock that were not contracted as well as solutions for the possible economic damage. This chapter focuses on the following questions:

1. Which measures have been taken by the governments of the four MSs to support potato farmers and the processing industry to overcome the Covid-19 crisis?

2. How have these measures influenced the market situation of ware potatoes including the raw material price for the industry and the FPP volumes (stocks)?

\subsection{Large potato stocks at the moment of the first lockdown}

The main question in this section is: What was the market situation (volumes in stock) of processing potatoes at the moment of the Covid-19 outbreak in each Member States?

Prior to the inventory of measures per country, we make an inventory of the extent of the problems faced by the potato sector at the moment of the first lockdown (March/April 2021). In the beginning of the Covid-19 outbreak, the effects were small and mainly concentrated in China, but as the virus spread across the world and more and more countries entered into a lockdown effects also spread around the world. The negative consequences for the European potato processing industry became increasingly clear from February 2020 onwards.

Table 4.1 presents an overview of the volume potatoes processed in 2019, and the first estimation of potato volumes in stock on 1 April 2020 (including stocks of processing potatoes for export). These potato stocks have a limited shelf life and are normally processed until July at the latest. After that moment the shift is made to potatoes from the next harvesting season.

Table 4.1 Overview of processed volumes (2019) and estimation of processing potatoes in stock around 1 April 2020

\begin{tabular}{|c|c|c|c|c|}
\hline \multirow[t]{2}{*}{ Member State } & \multirow{2}{*}{$\begin{array}{c}\text { Potatoes processed } \\
\text { per year } \\
(* 1,000 \text { tonnes })\end{array}$} & \multicolumn{3}{|c|}{$\begin{array}{c}\text { Potatoes in stock (*1,000 tonnes) } \\
\text { estimation: } 1 \text { April } 2020\end{array}$} \\
\hline & & \multicolumn{3}{|c|}{ contracted or free } \\
\hline Belgium & 5,300 & 1,710 & 540 & 1,170 \\
\hline France & $\begin{array}{c}1,300 \text { of which } 2 / 3 \text { for } \\
\text { FPP }\end{array}$ & 1,030 & 130 & 900 \\
\hline Germany & $\begin{array}{l}3,600 \text { processed } \\
\text { of which } 1,100 \text { for } \\
\text { frozen products }\end{array}$ & 550 & 150 & 400 \\
\hline The Netherlands & 3,900 & 1,500 & 300 & 1,200 a) \\
\hline
\end{tabular}

a) including surplus potatoes

Source: EUPPA, Wageningen Economic Research. 
Stocks occur at two places in the potato value chain: on the farm, where potatoes are stored between harvest and delivery, and after processing into FPP in cold stores. The latter stocks are usually shortterm and of limited size for cost-technical reasons and therefore not inventoried. Dutch processors in particular reported that they temporarily stored part of their frozen potato products in cold stores during the first lockdown (Delleman, 2021; Engwerda, 2021; Montanari et al., 2021). However, storage capacity of processors is limited to the normal flow of production. Since cold storage is expensive and space consuming most producers do not have available storage to store extra FPP. Consumers also stored significant amounts of frozen potatoes during the first wave (Montanari et al., 2021).

\section{Belgium}

The Belgian potato processing industry processes about 5.3 million tonnes per year. In Belgium, an estimated 1.7 million tonnes of processing potatoes was in stock on 1 April, of which 750,000 tonnes was expected to be unprocessed due to Covid-19. These 750,000 tonnes concerned all free, not contract potatoes in stock and a limited part of the stock of contracted potatoes. This is because processors fulfilled their contractual obligations as much as possible and also maintaining a good long term relationship with their growers.

\section{France}

The potato production in France normally amounts to 2.6 million tonnes per year, 1.3 million of which is processed by own industry (excluding starch), of which 860,000 tonnes deep frozen. The remaining 1.7 million tonnes are exported, mainly to Belgian and Dutch processors. Around April 1 there was still more than 1.0 million tonnes of potatoes in stock of which a total 470,000 tonnes mostly in farmers' storages, which was expected not be processed.

\section{Germany}

Germany processes 3.5-4.0 million tonnes of potatoes annually and exports 1.5-1.75 million tonnes of domestic production to Belgium, the Netherlands and France. An estimated 550,000 tonnes of the potato stock on April 1 could not be processed, of which 400,000 tonnes were contracted potatoes. Of these contracted potatoes, 250,000 tonnes was for export (Belgium, the Netherlands) and 150,000 tonnes for inland plants.

\section{The Netherlands}

The Dutch potato sector estimated the stock of potatoes on April 1 at 1.5 million tonnes (contracted plus free potatoes). At that time it was expected that approximately $30 \%$ of this stock could be processed that season (till August), mainly contracted potatoes because processors had to fulfil their contracts (Janssens et al., 2020).

\subsection{Governmental measures and support per member state differ}

The main question in this section is: Which measures have been taken by the governments of the four MSs to support potato farmers and the processing industry to overcome the Covid-19-crisis?

\section{General support measures}

The Covid-19 outbreak affected many industrial sectors. The impacts of the Covid-19 pandemic on the EU food industries differs per subsectors, as the impacts are highly diverse. While subsectors with close links to the out-of-home-market were hit hardest, food retailers experienced increased sales. In general, the decline in food and drink industry production was much lower compared to total manufacturing production (-9.1\% in Q2 2019). Similarly, the employment levels in the food and drink industry decreased as well, but to a lesser extent than for total manufacturing. The supply chains of the food industries remained relatively resilient (De Vet et al., 2021).

In various sectors, the economic impact was such that governments launched general support programmes. These national programs varied by country and included a wide range of measures such 
as expenditure measures (e.g. temporary unemployment), tax measures, measures related to public guarantees and other measures than fiscal providing liquidity support (EC, 2020). Industries that were affected could appeal to these programs. Montanari et al. (2021) reports general Covid-19 measures for agri-food industry but no specific measures for the potato processing industry. The extent to which the potato processing industry in the four countries made use of temporary general national Covid-19 support programs is unclear and no specific data was available.

\section{Support for potato growers}

The urgent problems of non-processable stocks of processing potatoes in spring 2020 were addressed by representative organisations in the potato sector to the governments of their member states in April 2020 and afterwards. The potato sector in each MS asked for governmental support with the aim of limiting the financial damage from non-processable potatoes in stock. As a result, the Dutch and Belgian governments have set up temporary arrangements to support potato growers with nonprocessable stocks (Montanari et al., 2021). The German and French governments didn't set up such temporary arrangements to support their potato growers (Montanari et al., 2021). The core of the measures in Belgium and the Netherlands was to partially reimburse the costs of un-processable potatoes on the condition that these potatoes were only sold to sales channels outside the food segment, such as bioenergy, drying or feed.

Because the crisis broke out in the second half of the season, only that part of the growers who still had potatoes in storage, in particular long-term keepers, was affected. The support by Belgian and Dutch governments had limitations: only stocks of non-saleable free potatoes (including pool potatoes) still in storage were eligible for reimbursement. Contracted potatoes for processing were excluded from the support scheme. The regulations of MSs prescribe that no government compensation is paid for potatoes that are processed into FPP. This means no support is possible on contracted and free potatoes sold to the FPP industry (such a violation is punishable). The possibility that processors would pay the difference between the fee and up to the agreed contract price was also prohibited, due to the risk that this could be considered as, prohibited, double state aid to processors who could also claim other temporary governmental Covid-19 support packages.

\section{Belgium}

In Belgium, the provinces of Flanders and Wallonia introduced support for the potato sector affected by the Covid-19 pandemic. Flanders made a one-off amount of 10 million euros and Wallonia 10.45 million euros available to compensate affected processing potato growers (Flemish government, 2020; Wallonia government, 2020). The details of the support regulations were almost the same for both provinces.

Potato growers could receive compensation of 50 euros per tonne for non-saleable free, noncontracted, potatoes in stock on 15 May 2020. The first 100 tonnes were not eligible for compensation. Compensation was also provided for free potatoes that had been used to feed the own herd in the period from 13 March to 15 May 2020. The proceeds of the sale as animal feed were deducted from the 50 euro aid per tonne. The compensation scheme was intended for Flemish and Wallonia farmers only.

First, compensation was awarded to farms with a limited stock of non-saleable free potatoes up to a maximum of 500 tonnes. Within the constraints of the available budget, the remaining budget was then divided among the stock volumes above 500 tonnes with a maximum stock of 2,000 tonnes (Wallonia maximum 1,500 tonnes) of free potatoes (depending on the remaining budget possibly at a lower amount per tonne). Compensation was at all times limited to 20 tonnes of stored potatoes per hectare indicated in the collective application 2019.

Flemish potato growers could submit an application up to and including 28 August 2020. The Agriculture \& Fisheries Department handled all applications. A total of 429 potato growers in Flanders submitted an application for a Covid-19 payment. ${ }^{12}$ In total 233,459 tonnes of potatoes was offered for compensation, an average request per grower of 544 tonnes. The corona compensation was paid

\footnotetext{
${ }^{12}$ Antwerpen 16, Vlaams-Brabant 32, West-Vlaanderen 222, Oost-Vlaanderen 126 en Limburg 32.
} 
at the end of December 2020. With a total compensation of 5.19 million euros, the maximum budget was not exceeded (Landbouwleven, 2021).

Wallonia government decided to support potato growers on 22 October 2020. Wallonia potato growers could submit an application up to and including 13 November 2020. The Public Service of Wallonia Agriculture, Natural Resources and Environment - communicated that the total payments amounted to 2.73 million euros for 280 requests for assistance (Wallonia Government, 2020a). According to EUPPA informants, Wallonia growers declared 124,274 tonnes. It can be concluded that Belgian growers requested only about 8 million of the available amount of more than 20 million euros. This is in line with the limited FPP production decline of $1.4 \%$ in Belgium.

\section{The Netherlands}

On 8 May 2020 the Dutch government announced support to potato growers located in the Netherlands who had unsaleable free, not contracted potatoes in stock due to Covid-19

(Staatscourant, 2020). The Dutch government made a one-off amount of 50 million euros available (RVO, 2020). Potato growers could receive compensation for the unsalable free potatoes during the period from 16 March to 31 August 2020. The compensation was maximised to 60 euros per tonne. The regulation concerned potatoes destined for the food industry that processes ware potatoes into frozen and/or chilled-fresh potato products, wholesale (in retail packaging), and retail trade (in retail packaging). If more compensation was requested than the budget available, the compensation per tonne would be reduced. The compensation payment was set at a minimum of 1,000 euros and a maximum of 150,000 euros per applicant. Unsaleable free potatoes for which compensation was requested could only be sold for non-food purposes at a much lower price like feed, bioenergy, or drying industry. In addition to the government compensation, the grower received the sales proceeds (5-6 euros compensation plus $1-3$ euros per $100 \mathrm{~kg}$ instead of the expected higher price of processing potatoes under normal market conditions (13-14 euros per $100 \mathrm{~kg}$ ).

By 20 September 2020, approximately 1,200 growers had submitted provisional and final applications for 900,000 tonnes of processing potatoes and a request for 54 million euros. Because the conditions for compensation were not entirely clear at first, growers submitted more potatoes for compensation, like contracted potatoes. Because of this the number dropped to 47 million euros in October (783,000 tonnes; Boerderij 2020a). At the end of 2020 the Dutch government estimated it paid 40 million euros for approximately 670,000 tonnes to compensate losses of less than 1.000 growers (Boerderij, 2020b).

\section{Germany and France}

On June 11, the French Government announced that it would devote 10 million euros to the potato sector, affected by the consequences of the Covid-19 crisis. However, by the end of October 2020 there was no concrete plan or regulation developed. In Germany no support measures were announced. EUPPA members also indicate that there were no compensation schemes for processing potato growers in France and Germany.

\subsection{Effects of Covid-19 measures on the market situation and potato prices}

The main question in this section is: How have these measures influenced the market situation of ware potatoes including the raw material price for the industry?

\section{Decreased FPP sales stagnates processing}

As a result of the lockdown, FPP production was scaled down and fewer potatoes were processed than in the previous year. Throughout 2020, Belgium processed $6.0 \%$ less and The Netherlands $12.2 \%$ less potatoes than in 2019 (Table 4.2). The decline was less in Belgium, because their industry mainly serves retail, whereas in the Netherlands they mainly serve out-of-home. Covid-19 led to closure of restaurants (including fast food) and catering industry and stagnating sales of FPP to this market, whereas retail remained open. 
Table 4.2 Potatoes processed (in 1,000,000 tonnes) in Belgium and the Netherlands in 2019 and 2020

\begin{tabular}{llrr} 
& 2019 & 2020 & Change \\
Belgium & & 5.08 & 2020 tov 2019 \\
\hline Netherlands & 5.43 & $3.0 \%$ & $-12.2 \%$ \\
\hline
\end{tabular}

Sources: Belgapom, VAVI.

Figure 4.1 shows the huge impact of the Covid-19 crisis during the first lockdown period from March to June 2020 on the potato processing industry in the Netherlands. Especially in April and May, use of potatoes by the processing industry and produced FPP volumes were much lower than the same months a year earlier (2019). Although monthly figures for other countries are not available, it is very likely that production in other countries followed a more or less a similar trend.

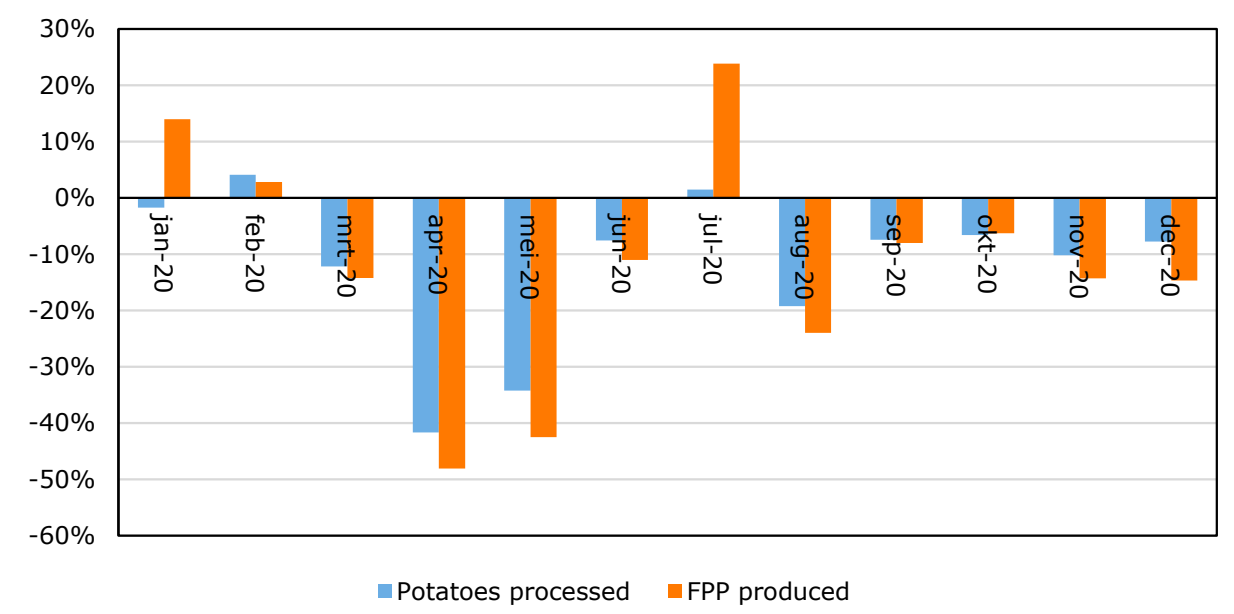

Figure 4.1 Change (2020 compared to 2019) in use of processing potatoes and FPP production per month in the Netherlands

Source: VAVI, analysis Wageningen Economic Research.

Differences between use of processing potato by the industry and FPP production are the result of processing efficiency and potatoes and FPP in stock.

\section{Potato prices}

The lockdown resulted in large stocks of unsaleable potatoes with a limited shelf life (see Table 4.1). These stocks were intended for processing during the period March-July 2020. After July a switch is made to processing the new harvest. At the end of the first quarter of 2020, which coincided with the start of the lockdown in the four countries, potato spot market prices in all countries fell extremely from around $14-16$ euros per $100 \mathrm{~kg}$ to $1-3$ euros per $100 \mathrm{~kg}$ (Figure 4.2). Even after the new harvest from August 2020 onwards, spot market prices remained low. This was because the out-of-homemarket remained below normal due to several lockdowns. The figure also shows differences in spot market prices between countries: Belgian prices were the lowest level, while Dutch prices were the highest. These low prices were caused by the fact that there was no demand from the processing industry for free market potatoes. Since processors had to comply with their contracted potatoes they could not take advantage of the low prices on the spot market. In this period very few transactions on the spot market were registered. 


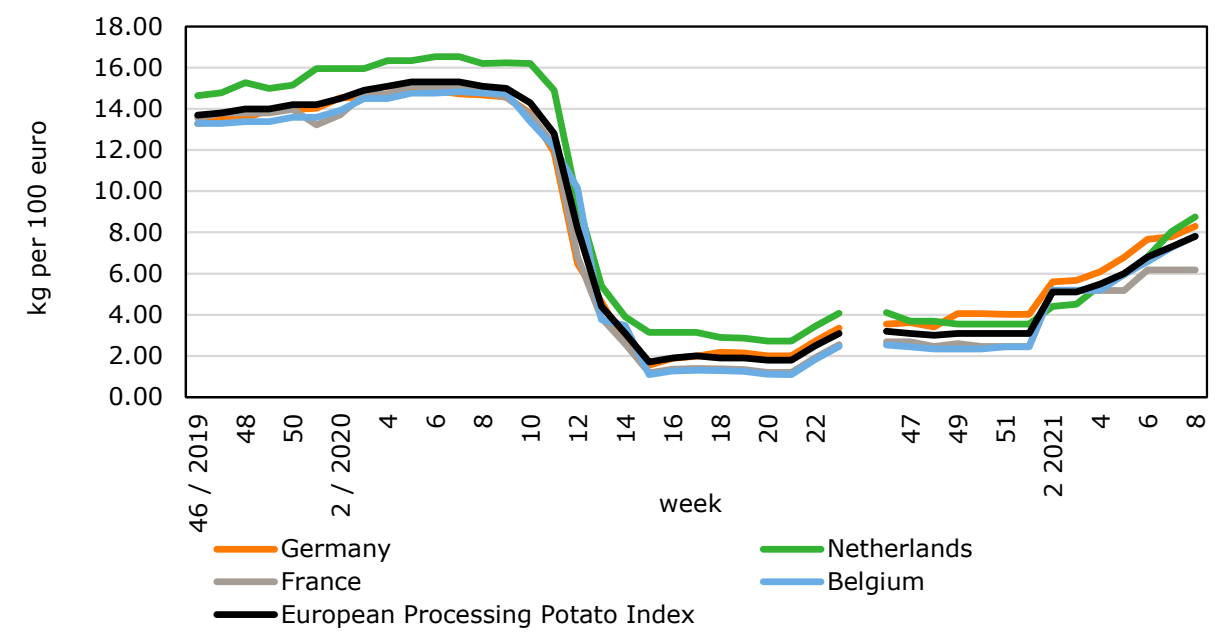

Figure 4.2 Development of processing potato spot market prices during season 2019-2020 Source: EEX.

Figure 4.3 illustrates the development of contract prices and spot market prices during the season 2019-2020 (variety Fontana, Belgium, Belgapom).

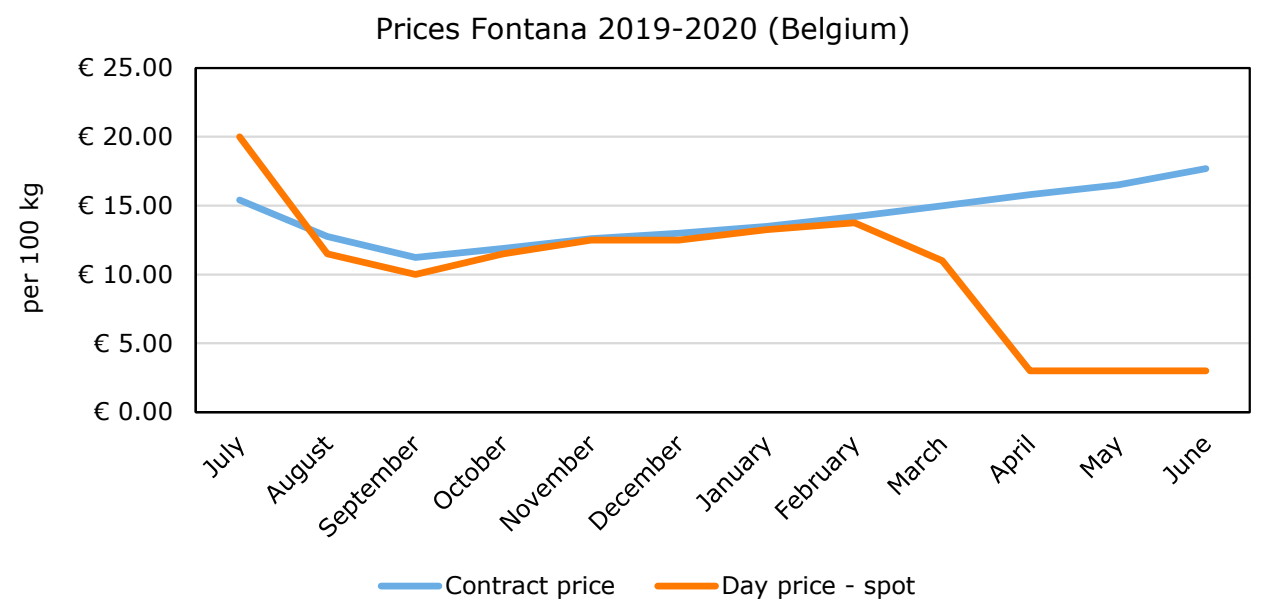

Figure 4.3 Development of processing potato spot market price and contract price of Fontana Source: Belgapom.

From the start of the season until February 2020, the spot market and contract price were almost at the same level. The spot market price then fell to the lowest level in a couple of weeks. The figure shows that the pandemic (during that specific season) had no effect on contract prices, but it had on day prices (spot market).

Measures did not affect potato prices

A central question is whether the Covid-19 support schemes influenced the potato contract and spot prices, i.e. the raw material prices for the potato industry:

- Contracted potatoes were excluded from support, which means that no direct or indirect effect of the government support on the contract prices is likely to have happened. These prices for the potatoes used in season 2019-2020, were agreed at the beginning of the season (January/February 2019), before the first lockdown period and impact of the Covid-19 crisis.

- The first lockdown led to a drastically changed market situation in which the supply of processing potatoes suddenly greatly exceeded demand, causing a huge drop in spot market prices (see Figure 4.1). The temporary support measures (application, approval and payment) were only announced and implemented after potato market disruption caused by the Covid-19 outbreak and 
first lockdown), so direct effects on potato market prices (spot market) between April and July 2020 can be excluded.

In addition the potato market transcends country borders; most of the potato production, including free potatoes, is in France and Germany, countries that have not established temporary support schemes for the potato sector. The temporary Dutch and Belgian support measures were intended to compensate unsaleable free potatoes to growers in these countries only, which is a limited share of the total potato market. The Belgian and Dutch support has no or hardly have any effect on the total Northwest European market where spot market prices are set by supply and demand.

The Covid-19 crisis did not affect agreements and fixed prices as set in contracts: contract agreements were fulfilled by the buyers/processors. Contracts and prices were mostly agreed just before or at the start of the season (January/February 2019). Buyers, mostly processors, have purchased these contracted potatoes at the agreed price. But, as mentioned before, very few spot market transactions were registered during that time.

Concluding, there is no indication that the Covid-19 support measures have had any effect on potato prices. Compensation measures for growers became clear a few months afterwards which makes it plausible that not the support-measures but the market situation, with an extreme decrease in demand and an unchanged supply, has determined the potato price level on the spot market. Moreover, the compensation in countries was limited with only part of the costs per tonne being reimbursed and not the full market price or cost.

\subsection{Summary and conclusions}

The research questions in this chapter were:

1. Which measures have been taken by the governments of the four MSs to support potato farmers and the processing industry to overcome the Covid crisis?

2. How have these measures influenced the market situation of ware potatoes including the raw material price for the industry and the FPP volumes (stocks)?

No specific Covid-19 support measures and data were found for the potato processing industry. They could use general temporary Covid-19 support measures that each country put in place (e.g. partly cost compensation in the event of a drop in turnover, tax measures). Belgium and The Netherlands implemented specific Covid-19 measures to support potato growers, terms, budgets and fees were country specific (see Chapter 4.2). These measures were temporary and only intended for potatoes in stock from the harvest of 2019 at the moment of the Covid-19 outbreak. This means that the time span of the support measures was limited to the first lockdown period only (March 2020 - July 2020). Covid-19. Only free, not-contracted potatoes owned by farmers were eligible for the support. Because the temporary support measures for the potato sector were implemented after potato market disruption caused by the Covid-19 outbreak and first lockdown there was no direct effect or influence of these measures on the free potato spot market. There is also no clear influence of Covid-19 support on raw material prices for FPP processing: these prices were mostly set by the disturbed market situation of a slightly decreased supply and a strongly decreased demand worldwide. 


\section{Covid-19 affects FPP export prices}

This chapter focusses on the FPP exports and especially on the question how Covid-19 outbreak affected export FPP prices and whether FPP export prices on the EU internal market were more influenced by Covid-19 than external FPP export prices. This question is divided into three subquestions:

1. Do governmental support through CAP and Covid-19 measures on ware potatoes effect FPP prices?

2. Is there price differentiation between intra- en extra-EU FPP-prices of European origin, discerned for the four MSs before the Covid-19 outbreak (pre Covid-19)? If so, how can price differences be explained?

3. Does Covid-19 or governmental support through CAP or Covid-19-measures lead to (more or less) price differentiation between intra- en extra-EU FPP-prices of European origin?

To answer the questions 2 and 3 the monthly EU internal and EU external FPP export prices were compared. Prior to this, we outline the export of FPP.

\section{Material and approach}

For the price analysis, data about export value in euro and volume in $\mathrm{kg}$ was retrieved from COMEXT for FPP for each of the four countries. The price per kg product were estimated by dividing export value by export volume. COMEXT distinguishes three FPP groups:

- 20041010 - Cooked potatoes, frozen

- 20041091 - Potatoes, prepared or preserved in the form of flour, meal or flakes, frozen

- 20041099 - Potatoes, prepared or preserved otherwise than by vinegar or acetic acid, frozen (excl. cooked only and in the form of flour, meal or flakes).

French fries is the main product of the product group cooked potatoes. The other two product groups include specialities, such as potato croquettes and rösti.

Intra-EU export figures include exports to the UK because this country was EU member until 2020. Annual figures per country for the period 2010-2019 were used for the analysis of long-term effects. Monthly figures for the period January 2015 - November 2020 were used to analyse the monthly developments of export prices because the impact of Covid-19 in early 2020 led to large potato price fluctuations between months for free market potatoes (see chapter 4) and the question is whether similar effects occur on FPP export prices.

The analyses of export prices were performed at country level for the largest product group (cooked potatoes, frozen), that made up $96 \%$ and $79 \%$ of extra-EU exports and intra-EU exports of FPP respectively, and for all three product groups combined. Statistical analysis (observation-mean value comparisons) have been done to substantiate the effect of Covid-19 crisis on average FPP export prices. Monthly FPP export prices before Covid-19 (January 2015 - March 2020) have been compared with the prices during the first Covid-19 lockdown period (April 2020-November 2020). Via a regression analysis (T-test), the FPP price difference between intra-EU and extra-EU over the period before the lockdown (January 2015 - March 2020) was compared with the period during that (April 2020-November 2020). ${ }^{13}$

\footnotetext{
${ }^{13}$ A time series OLS regression has been done, where dummy variables were added for the months during which Covid19 was prevalent. Then it was tested whether the coefficients for these dummy variables were significantly different from zero using a t-test.
} 


\subsection{No effect of CAP and Covid-19 on potato prices and FPP prices}

The purchase of potatoes is part of the cost of FPP production. The previous chapters indicate that there was no effect of CAP measures (Chapter 3) and no effect of governmental Covid-19 support on potato prices (Chapter 4). So there is no influence of CAP and Covid-19 support on raw material prices for FPP production. This means that neither CAP nor Covid-19 support had an impact on the raw material price of FPP and did not have an impact on FPP production costs. The price of the raw material for the processing industry depends on their raw material portfolio and the distribution between volumes of contracted and free potatoes (spot market) and their prices. Also discounts and surcharges due to tuber quality and grading and transport cost determine the price. Because CAP and the temporary Covid-19 governmental support had no effect on the potato spot market prices or on the contract prices, there was no direct effect of this support on the raw material price and on FPP prices. FPP sales prices are the result of supply and demand. In order to guarantee the continuity of potato processing companies, the sales need to cover the costs. Besides domestic sales, FPP are also exported within and outside the EU.

\subsection{Differences in intra-EU and extra-EU export prices}

The total Intra-EU and Extra-EU export volume of FPP increased during the last decade, (Figure 5.1). Especially from the main FPP production countries Belgium and the Netherlands, exports have increased. In 2019, these two countries together accounted for almost $84 \%$ of the total EU FPP exports (compare figures 5.1 and 5.2). The FPP export from Belgium increased annually, while the Dutch volume stabilised from 2016 onwards. The large potato processors in both countries serve different market segments: Belgian FPP products are mainly intended for the retail sector, while Dutch processors mainly serve the out-of-home-segment.

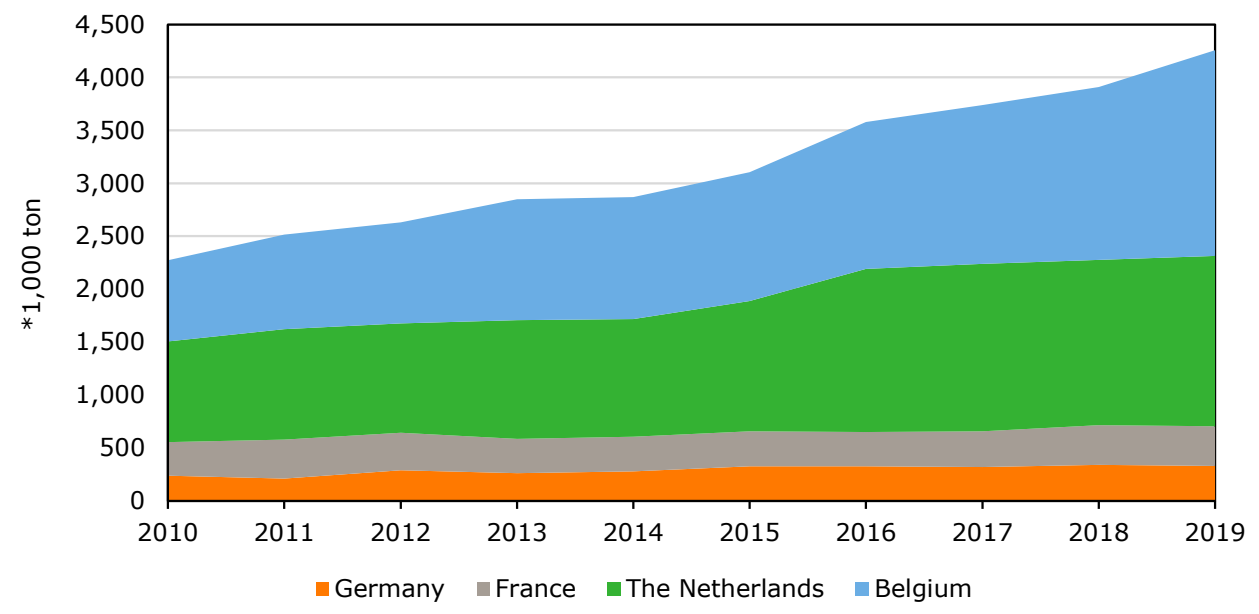

Figure 5.1 Development of total Intra-EU and Extra-EU exported volume FPP, all product groups. Source: Comext; analysis Wageningen Economic Research. 

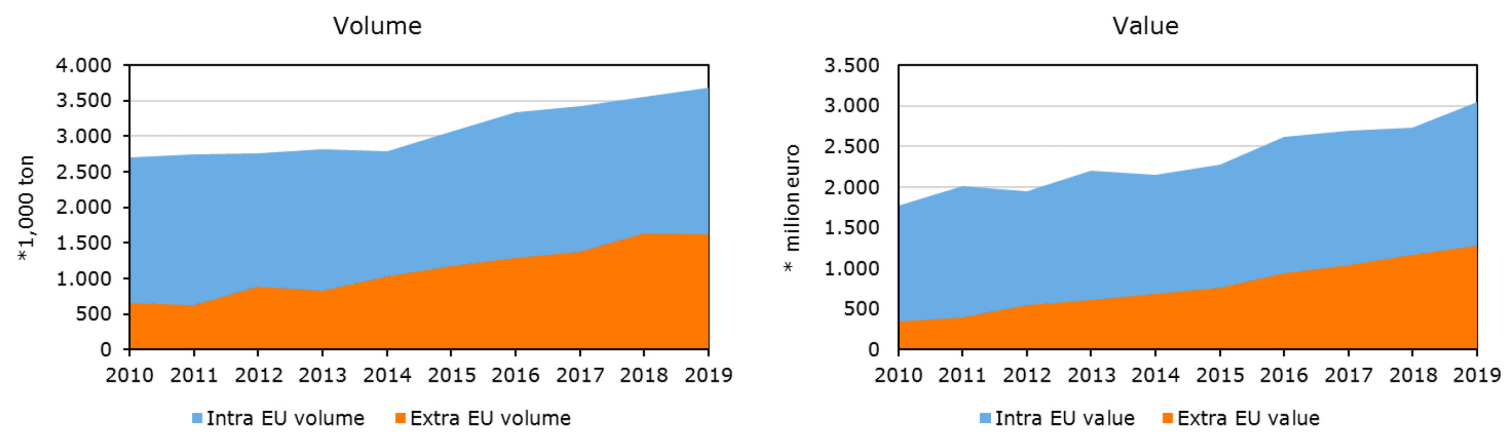

Figure 5.2 Development of Intra-EU and Extra-EU FPP export value and volume, all FPP 3 product groups cooked potatoes frozen, prepared potatoes), 4 MSs (Belgium, France, Germany and the Netherlands)

Source: Comext; analysis Wageningen Economic Research.

In $2019,70 \%$ of the total FPP exports of the four Member states were sold within the EU-28 (Figure 5.2). The total export value of FPP doubled since $2010(+52 \%)$ where the extra-EU export value $(+73 \%)$ increased more than the intra-EU export $(+42 \%)$. In 2019 , the volume share of the product group 'cooked potatoes, frozen' was $89 \%$ of all export of FPP. This product group made up $96 \%$ of the extra-EU export and $79 \%$ of the intra-EU export. These figures show that relatively more specialties (e.g. potato croquettes, rösti) are sold within the EU and that exports outside the EU consist to a greater extent of French fries.

Increasing FPP export prices

The FPP average export price of the four countries to all their export countries worldwide has increased since 2010 from 0.62 to 0.82 euro per $\mathrm{kg}$ in 2019 (Figure 5.3). Figure 5.3 also shows that the average prices over all three product groups is structurally higher than the prices of the product group 'cooked potato, frozen', indicating that specialty prices are structurally higher than prices for French fries.

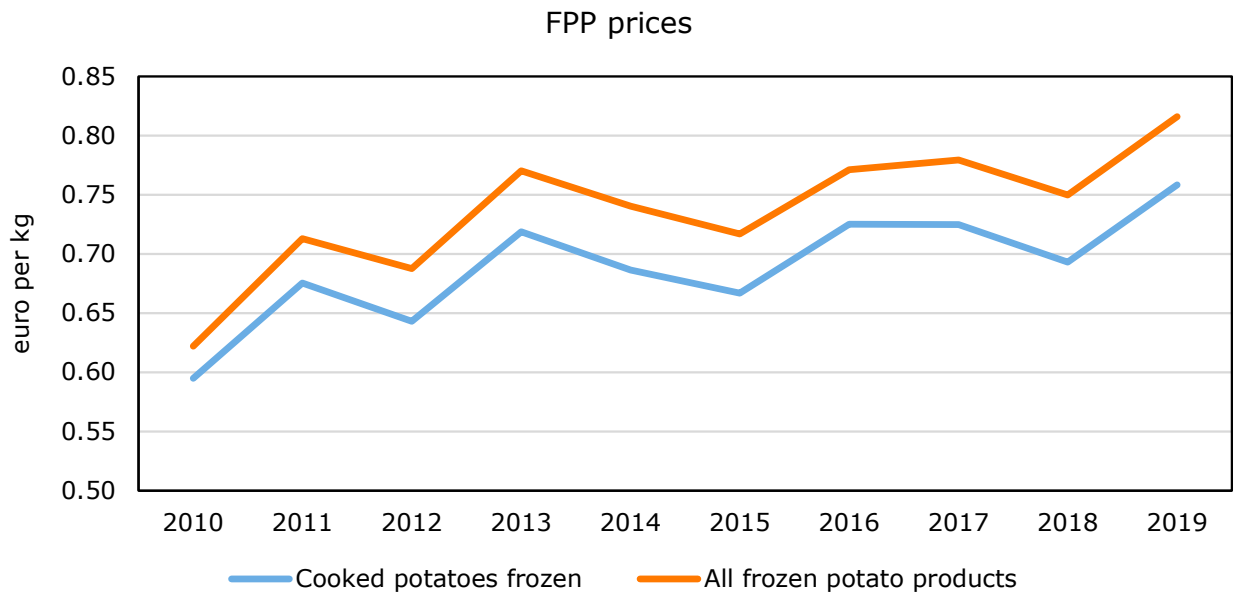

Figure 5.3 Development of total FPP export prices, 4 MSs, all 3 FPP product groups Source: Comext; analysis Wageningen Economic Research.

Table 5.1 shows that in each of the four Member States average intra-EU export prices are structural higher than extra-EU export prices but it cannot simply be concluded that the Extra-EU export prices from each of the four countries are monthly lower than what is sold from those countries within Europe. Table 5.1 shows the results of further analysis of the price difference per country.

Table 5.1 Average FPP export prices (all products, euro per kg FPP), 2010-2019 


\begin{tabular}{lrrrr} 
Type of export & Germany & France & The Netherlands & Belgium \\
Intra-EU & 0.99 & 0.89 & 0.80 & 0.65 \\
\hline Extra-EU & 0.97 & 0.65 & 0.70 & 0.64 \\
\hline
\end{tabular}

Source: Comext; analysis Wageningen Economic Research.

Remarkable observations among these price differences are:

- There was a significant FPP export price difference between the countries. Belgian FPP export prices were considerably lower than from the other countries, whereby it should be noted that Belgium was the largest exporter with a focus on products for consumers in the retail market while other countries like the Netherlands had a focus on products for the out-of-home-market segment with a higher value. The low-cost strategy in Belgium is also evident in FPP production: Belgian processors buy potatoes at the lowest spot market prices (see Figure 4.2 on potato spot market prices). France and Germany are small FPP producers (see Table 2.1) who mainly focus on their domestic market.

- The extra-EU export price in all four countries was lower than the Intra-EU export price, but the differences varied enormously between countries. An explaining factor for lower Extra-EU export prices is that FPP export outside the EU is directed to a spot market while intra EU-export is mainly contract based. FPP spot market prices are related to the current potato spot market prices (EUPPA information). For Belgium and Germany, intra-EU and extra-EU export prices were almost at equal level, while for France export prices differed 0.24 euro per kg FPP. In addition to product differentiation, sales methods and agreements (mostly long term contracts within the EU and free market tenders outside EU) were also important. The FPP extra-EU export market is mainly a free market (spot prices), while on the intra-EU export market annual contracts are more common. Beside contracted or free market sales intra-EU and extra-EU FPP price differences can also be explained by market segmentation (retail, out-of-home), product differentiation (specialties or chips, and premium, private label, or unlabelled) differences in product quality (chips length and classification) and packaging.

\subsection{No significant influence of Covid-19 on FPP price difference}

In this section we examine whether the Covid-19 crisis had an impact on FPP prices and in particular the differentiation between intra-EU and extra-EU FPP export prices. Because of the observed export price differences between the four countries in Section 5.1, we worked out this analysis country by country. For this analysis, Comext monthly FPP data of all three product groups was used for the period January 2015 to November 2020.

\section{Belgium}

Belgium is the largest producer and exporter of FPP of the four countries with at least $50 \%$ of the total intra-EU and extra-EU FPP exports. Figure 5.4 and 5.5 show that both before and after the first Covid19 lockdown, the difference between intra-EU and extra-EU export prices in Belgium was small and that extra-EU and intra-EU FPP export prices varied over time. 
All FPP products; Belgium

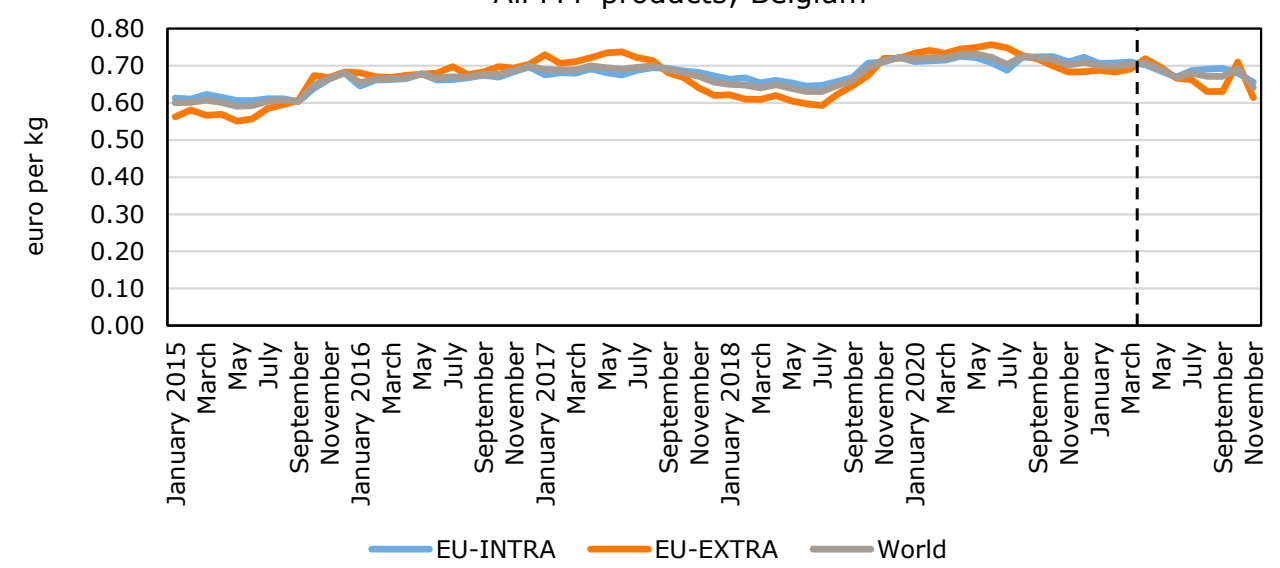

Figure 5.4 Development of monthly Belgian export prices for all FPP products Source: Comext; analysis Wageningen Economic Research.

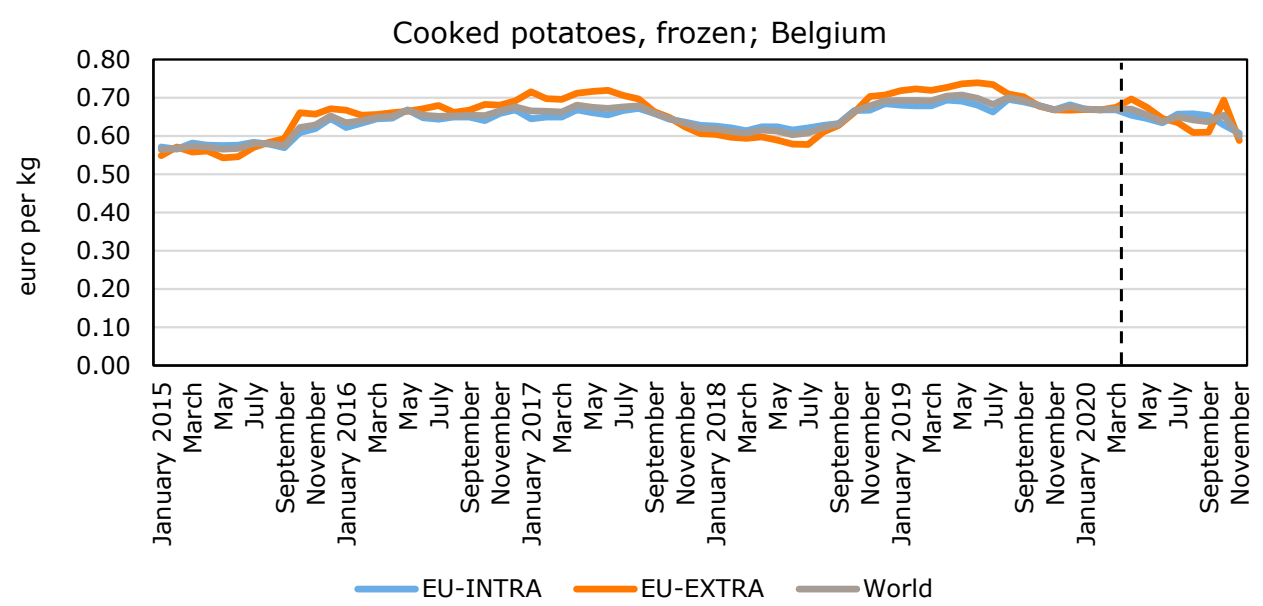

Figure 5.5 Development of monthly Belgian export prices for cooked potatoes, frozen Source: Comext; analysis Wageningen Economic Research.

As indicated previously, the Belgian FPP industry mainly produces for the retail market. Retail was relatively unaffected by Covid-19, because consumers bought even more because the catering industry was closed by most governments. There was however still a decrease in production in Belgium since they were also affected by the closure of the out-of-home segment, however less than in other producing countries. Table 5.2. shows average prices for all FPP products (fries and specialties) and for cooked potatoes, frozen (mainly French fries) only.

Table 5.2 Average pre and post Covid-19 monthly FPP export prices from Belgium (euro per kg FPP)

\begin{tabular}{lccccc} 
Export & \multicolumn{3}{c}{ All FPP products } & & Cooked potatoes, frozen \\
\cline { 2 - 6 } destination & $\begin{array}{c}\text { January 2015 } \\
\text { - March 2020 }\end{array}$ & $\begin{array}{c}\text { April 2020- } \\
\text { November 2020 }\end{array}$ & Difiference & $\begin{array}{c}\text { January 2015 } \\
\text { March 2020 }\end{array}$ & $\begin{array}{c}\text { April 2020- } \\
\text { November 2020 }\end{array}$ \\
EU-INTRA & 0.674 & 0.683 & $1.3 \%$ & 0.642 & 0.642 \\
\hline EU-EXTRA & 0.670 & 0.666 & $-0.6 \%$ & 0.665 & $-1.7 \%$ \\
\hline $\begin{array}{l}\text { Intra minus } \\
\text { Extra }\end{array}$ & 0.004 & -0.017 & & -0.023 & -0.002 \\
\hline
\end{tabular}

Source: Comext; analysis Wageningen Economic Research. 
The average Belgian intra-EU export prices of all FPP products during the lockdown were $1.3 \%$ above the average price before the lockdown, while the intra-EU price of the largest product group (Cooked products, frozen) remained the same. The average Belgian extra-EU export price of all FPP products was $0.6 \%$ lower during the lockdown than before the lockdown, and the extra-EU export price of cooked potatoes, frozen was $1.7 \%$ lower. It shows that Belgian extra-EU export prices dropped more sharply during the lockdown compared to Belgian intra-EU export prices.

The regression analysis showed that for both product groups (the price difference between intra-EU and extra-EU export prices during the lockdown was not significantly different lockdown from that before the lockdown ( $t$-values were -0.81 and 1.33 respectively).

France

Compared to Belgium and the Netherlands, France exports small volumes of FPP and most of French exports are intra-EU. Figure 5.6 (all product groups) and 5.7 (product group cooked potatoes, frozen) show the development of French FPP export prices 2015-2020 and that export prices from mid-2018 and during the first Covid-19 wave export prices show very small differences.

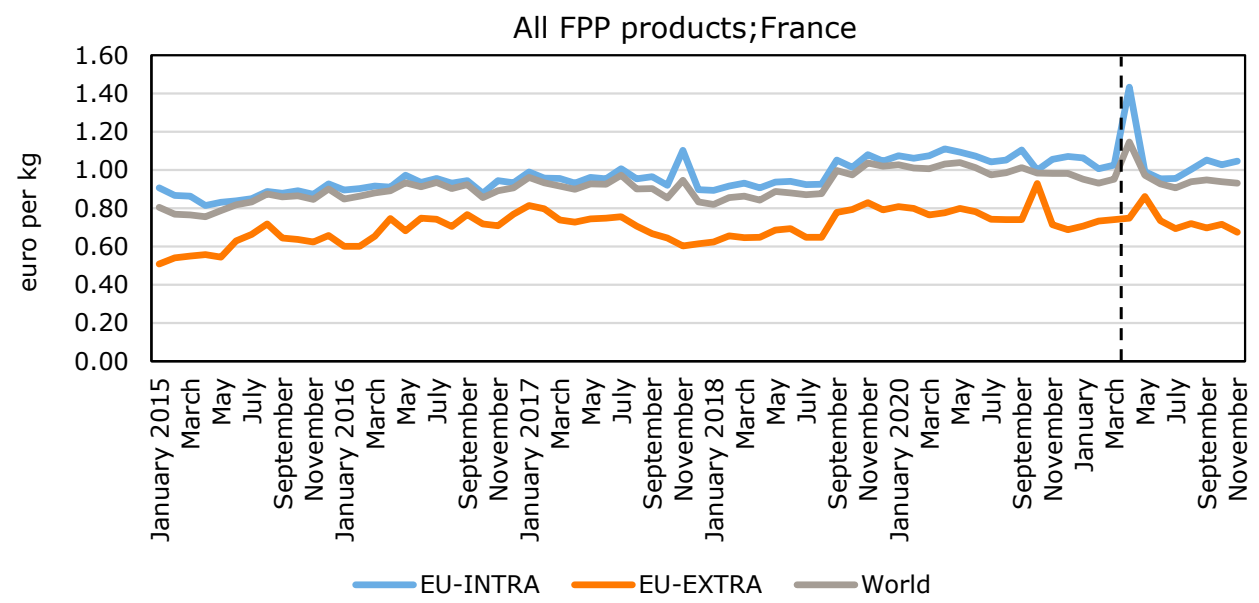

Figure 5.6 Development of monthly French FPP export prices for all FPP products (2015-2020). Source: Comext; analysis Wageningen Economic Research.

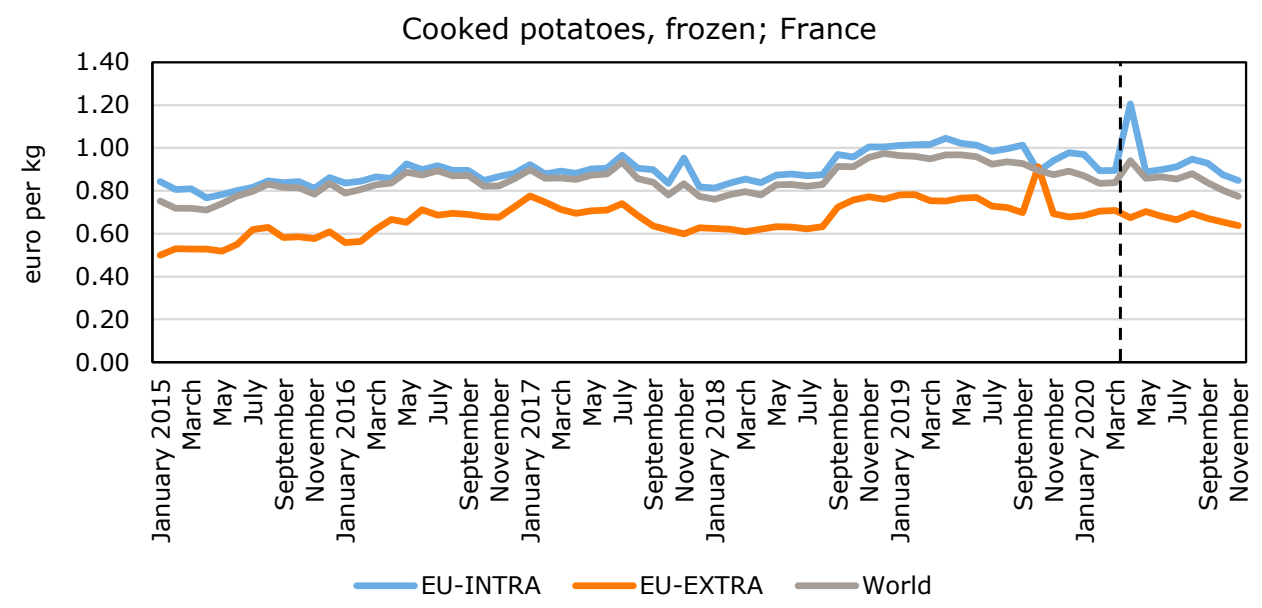

Figure 5.7 Development of monthly French FPP export prices for cooked potatoes, frozen (20152020)

Source: Comext; analysis Wageningen Economic Research. 
At the start of the lockdown (April 2020), French export prices peaked, which may be related to temporary hoarding behaviour of consumers and logistic problems. Belgian (Figure 5.4) and German (Figure 5.8) Extra-EU export prices peaked as well but less extreme at that moment. During the first wave both intra-EU and extra-EU export prices of cooked potatoes, frozen decreased (Figure 5.7) while French intra-EU export prices of specialties increased (Figure 5.6). Table 5.3 shows the impact of Covid-19 on the French FPP export prices.

Table 5.3 Average pre and post Corona monthly FPP export prices from France (euro per kg FPP)

\begin{tabular}{lccccc} 
Export & \multicolumn{3}{c}{ All FPP products } & \multicolumn{2}{c}{ Cooked potatoes / chips } \\
\cline { 2 - 6 } destination & $\begin{array}{l}\text { January 2015 } \\
\text { - March 2020 }\end{array}$ & $\begin{array}{c}\text { April 2020- } \\
\text { November 2020 }\end{array}$ & Difierence & January 2015 & April 2020- \\
- March 2020 & November 2020 \\
EU-INTRA & 0.962 & 1.058 & $9.9 \%$ & 0.898 & 0.938 \\
\hline EU-EXTRA & 0.702 & 0.731 & $4.2 \%$ & 0.668 & 0.673 \\
\hline Intra minus Extra & 0.261 & 0.327 & & 0.230 & $0.7 \%$ \\
\hline
\end{tabular}

Source: Comext; analysis Wageningen Economic Research.

Differences between average French prices of intra-EU and extra-EU FPP sales have increased since the first lockdown, especially for all FPP products (specialties). It should be noted that the price peak in April affects the average intra-EU price of FPP. Over the period May-November 2020, the average is lower and more close to the pre-lockdown period: 1.004 euros per kg FPP all products and 0.900 euros per $\mathrm{kg}$ cooked potatoes frozen.

Via a regression analysis, the French FPP price difference between intra-EU and extra-EU over the period before the Covid-19 outbreak (January 2015 - March 2020) is compared with the period after that lockdown (April 2020-November 2020). This analysis for both product groups shows that, although the Covid-19 outbreak put pressure on French export prices, the difference between intra-EU and extra-EU FPP prices during the lockdown did not differ significantly from those before the lockdown.

\section{Germany}

Like France, Germany is a small FPP exporter. Eighty per cent of the German FPP exports go to European countries. German FPP export prices are the highest of all four countries. Figure 5.8 and 5.9 show the development of FPP prices 2015-2020 and the increasing difference between intra-EU and extra-EU export prices after the lockdown in March 2020, mainly due to falling German extra-EU export prices during the first wave

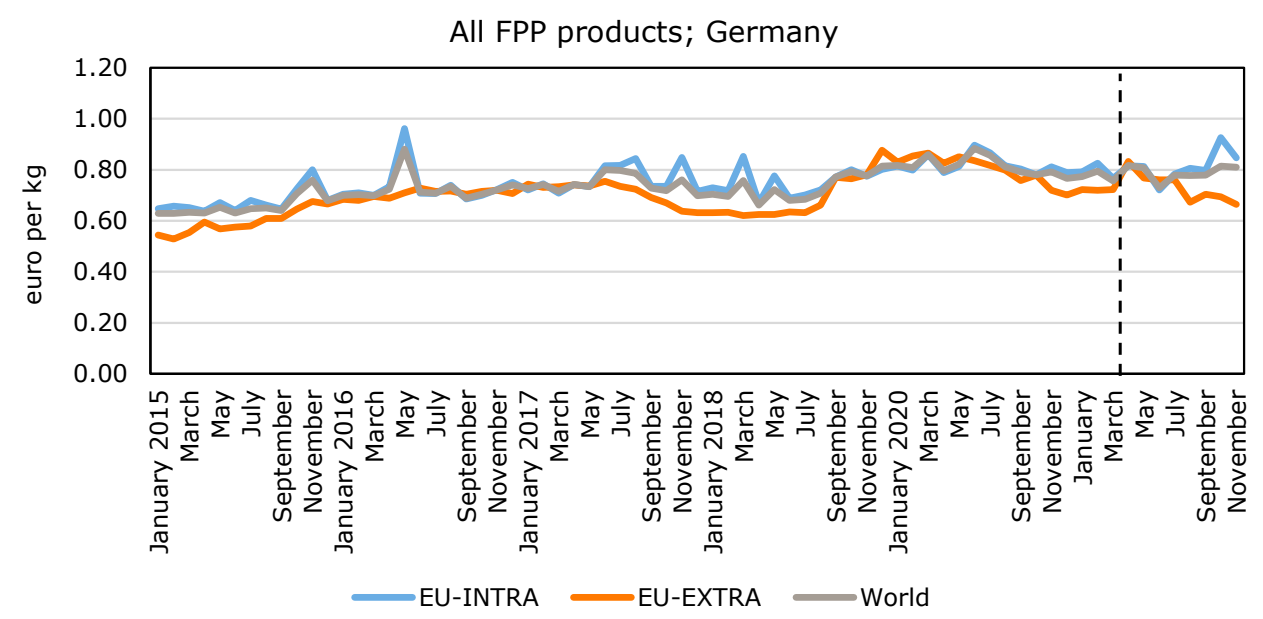

Figure 5.8 Development of monthly German FPP export prices for all FPP products, 2015-2020 Source: Comext; analysis Wageningen Economic Research. 


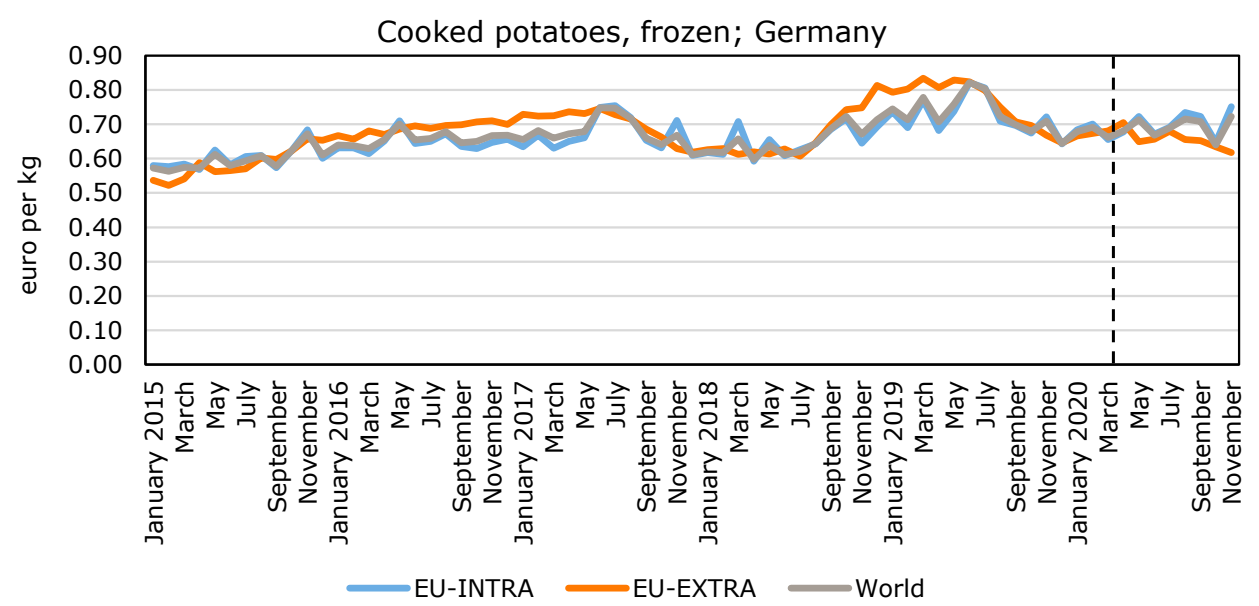

Figure 5.9 Development of monthly German FPP export prices for cooked potatoes, frozen, 20152020

Source: Comext; analysis Wageningen Economic Research.

Table 5.4 shows the impact of Covid-19 on the German FPP intra-EU and extra-EU export prices.

Table 5.4 Average pre and post Corona FPP export prices from Germany (euro per kg FPP)

\begin{tabular}{lcccccc}
\multirow{2}{*}{$\begin{array}{l}\text { Export } \\
\text { destination }\end{array}$} & \multicolumn{3}{c}{ All FPP products } & \multicolumn{3}{c}{ Cooked potatoes / chips } \\
\cline { 2 - 8 } & $\begin{array}{c}\text { January 2015 } \\
\text { - March 2020 }\end{array}$ & $\begin{array}{c}\text { April 2020- } \\
\text { November 2020 }\end{array}$ & Difference & $\begin{array}{c}\text { January 2015 } \\
\text { - March 2020 }\end{array}$ & $\begin{array}{c}\text { April 2020- } \\
\text { November 2020 }\end{array}$ & Difference \\
EU-INTRA & 0.751 & 0.814 & $8.4 \%$ & 0.660 & 0.702 & $6.4 \%$ \\
\hline EU-EXTRA & 0.702 & 0.732 & $4.2 \%$ & 0.680 & 0.656 & $-3.5 \%$ \\
\hline Intra minus Extra & 0.049 & 0.082 & & -0.020 & 0.046 & \\
\hline
\end{tabular}

Source: Comext; analysis Wageningen Economic Research.

During the first lockdown, German intra-EU export prices were higher than before the lockdown for both product groups. The average EU-Extra export price of all products during the lockdown was above the price before the lockdown, but for the largest product group (cooked potatoes, frozen), the average extra-EU export price during the lockdown was 3.5\% lower the average price before the lockdown. The regression analysis showed that for both product groups the difference between the average intra-EU and extra-EU export price during the lockdown was significantly higher than before the lockdown.

\section{The Netherlands}

The Netherlands is the second largest FPP exporter of the four countries and produces FPP mainly for the out-of-home-market. Figure 5.10 and 5.11 show the development of Dutch FPP export prices 2015-2020 and the increasing difference between Intra-EU and Extra-EU export prices after the lockdown in March 2020. 


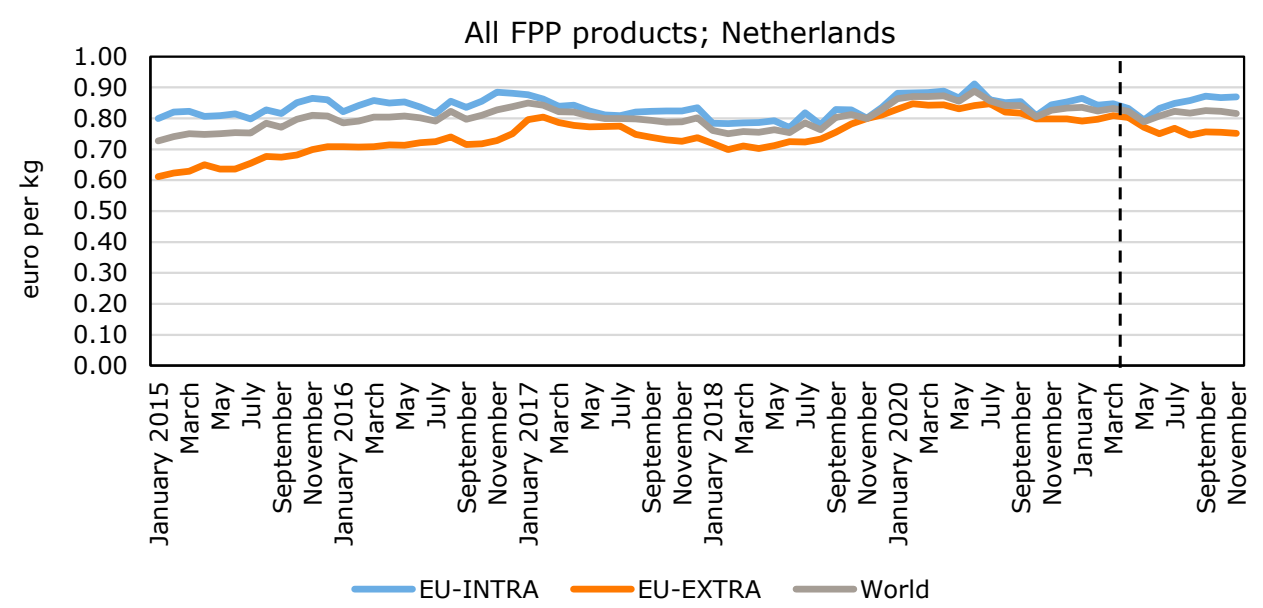

Figure 5.10 Development of monthly Dutch FPP export prices for all FPP products (2015-2020) Source: Comext; analysis Wageningen Economic Research.

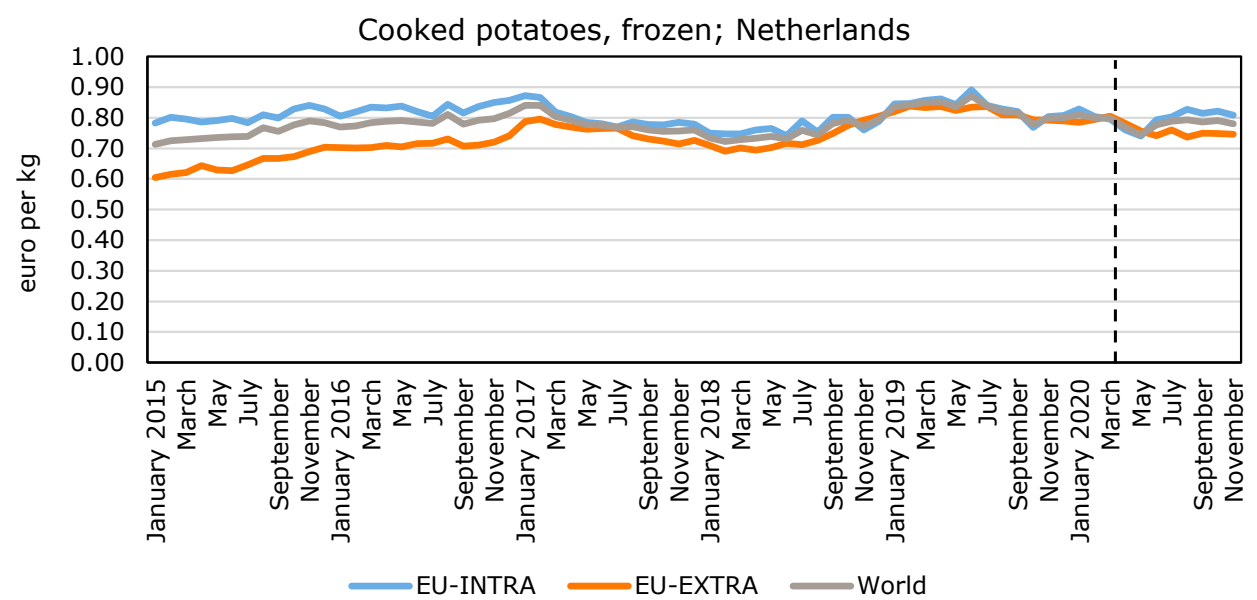

Figure 5.11 Development of monthly Dutch FPP export prices for cooked potatoes, frozen (20152020)

Source: Comext; analysis Wageningen Economic Research.

From 2015, the Dutch extra-EU export price for both product groups (figures 5.11 and 5.12) were below the intra-EU export prices, but the difference narrowed over time. After the Covid-19 outbreak, the price differential increased, mainly because extra-EU export prices fell.

Table 5.5 shows the impact of Covid-19 on the Dutch FPP export prices.

Table 5.5 Average pre and post Corona FPP prices the Netherlands (euro per kg FPP)

\begin{tabular}{|c|c|c|c|c|c|c|}
\hline \multirow{3}{*}{$\begin{array}{l}\text { Export } \\
\text { destination }\end{array}$} & \multicolumn{3}{|c|}{ All FPP products } & \multicolumn{3}{|c|}{ Cooked potatoes / chips } \\
\hline & January 2015 & April 2020- & Difference & January 2015 & April 2020- & Difference \\
\hline & - March 2020 & November 2020 & & - March 2020 & November 2020 & \\
\hline EU-INTRA & 0.835 & 0.847 & $1.4 \%$ & 0.807 & 0.796 & $-1.4 \%$ \\
\hline EU-EXTRA & 0.744 & 0.763 & $2.5 \%$ & 0.736 & 0.753 & $2.2 \%$ \\
\hline Intra minus Extra & 0.091 & 0.084 & & 0.071 & 0.044 & \\
\hline
\end{tabular}

Source: Comext; analysis Wageningen Economic Research.

The average Dutch extra-EU export price during the lockdown was higher than the average price before it; extra export prices were low and increased gradually (see Figures 5.10 and 5.11). The intra- 
EU export price of cooked potatoes frozen during the lockdown was $1.4 \%$ lower compared to average price before the lockdown of this group. For both groups, the difference between the average intra-EU and extra-EU prices became smaller during lockdown compared to the difference before the lockdown. The regression analysis confirms that the price difference between Dutch intra-EU and extra-EU before and after the lockdown did not differ significantly.

\subsection{Summary and conclusions}

The main questions considered in this chapter are:

1. Is there price differentiation between intra- and extra-EU FPP-prices of European origin, discerned for the four MSs before the Covid-19 outbreak (pre Covid-19)? If so, how can price differences be explained?

2. Does Covid-19 or governmental support through CAP or Covid measures lead to (more or less) price differentiation between intra- en extra-EU FPP-prices of European origin?

Main findings:

- Extra-EU FPP export prices in all four countries were on average lower than intra-EU FPP export prices. The difference between them differs between the countries. Product portfolio, differences in product specifications and commercial activities of the potato processing industry were important causes for price differences. Belgium, that produces mainly FPP for the retail market, has the lowest prices while for example Dutch potato processors produce more expensive FPP for the out-of-home market. An additional explaining factor for lower Extra-EU export prices is that FPP export outside the EU is directed to short term sales while intra EU-export is mainly contract based and spot market has lower prices than contract. This way potato cost at a specific time determines the sales price while long term contracts are based on longer term average potato costs. FPP spot market prices are related to the current potato spot market prices (EUPPA information).

- During the Covid-19 crisis (March-November 2020), the difference between intra-EU and extra-EU FPP export prices was not significantly different from the difference in the period before covid. For all countries, the Covid-19 outbreak led to an underpricing trend on the FPP export prices. However, regression analysis does not show that the underpricing trend is significant, except for Germany, which is a small FPP exporter. 


\section{Conclusions}

In this section the answers to the main research questions that have been obtained in the preceding chapters are summarised.

How have potato cultivation areas and FPP-production in the four major FPP-producing MSs of the EU developed in the last decade and which effect had Covid-19 on area and production?

Within the group of four Member States studied, Germany and France produce the largest volume of potatoes yearly. The total potato acreage in Belgium, France, Germany and the Netherlands increased in recent years. Potato production increased as well but was hit by drought, especially in the years 2018 and 2020. The Covid-19 crisis did not have an impact on the development of the planted potato area in 2020 in the four countries; most potatoes had already been planted when the crisis became apparent (March-April 2020). Belgium was the largest FPP producer, followed by the Netherlands. Both countries imported a substantial quantity of potatoes from Germany, France, and other neighboring countries. Due to the Covid-19 crisis, FPP production decreased in 2020 in all four countries, especially countries serving the out-of-home market. A significant proportion ( $>65 \%$ ) of the ware potatoes used for processing were contracted, be it with various types of contracts.

Why does the EU support farms through CAP and how is the CAP-support for arable farms organised? How does this influence profitability of ware potato growing and the potato market in the EU in general and in the four MSs specifically?

The EU has supported its farmers from the beginning in the 1960s. Initially support was mainly provided as price support, combined with border protection. Since the 1990s price support has been largely dismantled and has been replaced by direct payments, which in the course of time have been largely decoupled from production. Our analysis shows that the CAP has evolved from a general production support system for agricultural production in the EU after the World War II to an increasingly market oriented policy with income support being decoupled form production and an increasing emphasis on environmental sustainability, climate action and rural development support.

The ware potato sector never received any significant targeted support from the CAP nor by area nor by price. Ware potato has never been included as a supported crop in the Common Market Organisation of the EU.

Which measures have been taken by the governments of the four MSs to support potato farmers and the processing industry to overcome the Covid crisis? How have these measures influenced the market situation of ware potatoes including the raw material price for the industry and the FPP volumes (stocks) and prices?

In the four target countries no Covid-19 support measures were developed specifically for the potato processing industry. However, the industry was able to make use of general temporary Covid-19 support measures that each country put in place (e.g. partly cost compensation in the event of a drop in turnover, tax measures). Belgium and the Netherlands implemented specific Covid-19 measures to support ware potato growers. Terms, budgets and fees were country specific. These measures were temporary and only intended for potatoes from the harvest of 2019 that they kept in stock. The time span of the support measures was limited to period of March 2020 to July 2020.

The support measures aimed at affected farmers who still had stocks of potatoes in storage at the moment of the Covid-19 outbreak. Only free potatoes owned by farmers were eligible for the support; contracted potatoes and processors were excluded from any support measures. Because these temporary support measures were implemented after production decisions were made, there was no direct influence on the free potato market. In that period, spot market prices were at the lowest level 
due to the strongly decreased demand of the out-of-home sector because of lockdowns. There was no influence of Covid-19 support on FPP prices. These prices were mostly set by the disturbed market situation of a slightly decreased supply and a strongly decreased demand worldwide.

Is there price differentiation between intra- en extra-EU FPP-prices of European origin, discerned for the four MSs? If so, how can these price differences be explained?

Extra-EU FPP export prices were on average lower than intra-EU FPP export prices. This is because extra-EU FPP export outside was mainly short term sales (spot market) whereas the EU home market largely relied on contracted potatoes. The extent of the difference in prices varied between the four countries. In Belgium, potato processors produced mainly FPP for the retail market for the lowest prices, while in the Netherlands processors produced more expensive FPP for the out-of-home market. Product portfolio, differences in product specifications and commercial activities of the potato processing industry were key factors in explaining the observed price differences. Observed price differentiation between home and export market could not be linked to any kind of public support, neither in the short term (Covid-19 support), nor in the medium-term (CAP). 


\section{References and websites}

\section{Literature}

Berkhout, P., J. Helming, P.-W. Blokland, B. Smit, N. Polman and A. Greijdanus, 2021. Conditionaliteit in het GLB; Onderzoeksvarianten voor een verkenning van de deelnamebereidheid bij ondernemers in de primaire landbouw (Conditionality in CAP; Research variants for exploring the willingness of agricultural entrepreneurs to participate; in English with Dutch summary). Wageningen, Wageningen Economic Research, Report 2021-027. https://doi.org/10.18174/543867

Boerderij, 2020a. RVO gestart met betalen coronacompensatie fritestelers. https://www.boerderij.nl/Akkerbouw/Nieuws/2020/10/RVO-gestart-met-betalencoronacompensatie-fritestelers-651101E/

Boerderij, 2020b. Compensatie fritesaardappeltelers komt op 40 miljoen. https://www. boerderij. nl/Akkerbouw/Nieuws/2020/11/Compensatie-fritesaardappeltelers-komtop-40-miljoen-673702E/

CBS, 2016. Netherlands, Belgium largest french fries producers. https://www.cbs.nl/en$\mathrm{gb} /$ news/2016/39/netherlands-belgium-largest-french-fries-producers

Delleman, Jaap, 2021. Het is onze ambitie zoveel mogelijk waarde uit de aardappel te halen. Aardappelwereld Magazine, februari 2021, nummer 2.

De Cicco, A. and J.-C. Jeanty, 2019. The EU potato sector - statistics on production, prices and trade. Eurostat statistics explained. https://ec.europa.eu/eurostat/statisticsexplained/index.php/The_EU_potato_sector___statistics_on_production,_prices_and_trade.

De Vet, J.M., et al. Impacts of the COVID-19 pandemic on EU industries, Publication for the committee on Industry, Research and Energy, Policy Department for Economic, Scientific and Quality of Life Policies, European Parliament, Luxembourg, 2021. http://www.europarl.europa.eu/supportinganalyses

Delleman, Jaap, 2021. Het is onze ambitie zoveel mogelijk waarde uit de aardappel te halen. Aardappelwereld Magazine, februari 2021, nummer 2.

Dodde, H., 2019. LTO wil pijn van verlies Chloor IPC delen (LTO wants to share the pain of losing Chlorine IPC; in Dutch). Nieuwe Oogst (Weekly magazine of the Dutch Farmers Organisation, LTO). www.nieuweoogst.nl/nieuws/2019/10/28/lto-wil-pijn-van-verlies-chloor-ipc-delen

Dodde, H., 2020. Industrie dekt extra kosten voor wegvallen chloorprofam (Industry covers additional costs for loss chlorine profam; in Dutch). Nieuwe Oogst (Weekly magazine of the Dutch Farmers Organisation, LTO). https://www.nieuweoogst.nl/nieuws/2020/02/14/industrie-dekt-extra-kostenvoor-wegvallen-chloorprofam

EC, 2020. Policy measures taken against the spread and impact of the coronavirus - 16 November 2020.

EU, 2013. Regulation (EU) no 1308/2013 of the European Parliament and of the Council of 17 December 2013, establishing a Common Organisation of the Markets in agricultural products and repealing Council Regulations (EEC) No 922/72, (EEC) No 234/79, (EC) No 1037/2001 and (EC) No 1234/2007. Official Journal of the European Union L 347/671, 20.12.2013.

Europatat, 2016. Activity report 2016-2017. Brussels - Belgium. http://europatat.eu/wpcontent/uploads/2017/06/Europatat-activity-Report-2016-2017.pdf

Engwerda, Jan, 2021. CEO Chris Deen: '2021 wordt een beter jaar voor Aviko'. Boerderij https://www. boerderij. nl/ceo-chris-deen-2021-wordt-een-beter-jaar-voor-aviko

Flemish government, 2020. Steun voor land en tuinbouw coronavirus. https://www. vlaio, be/nl/subsidies-financiering/subsidiedatabank/steun-land-en-tuinbouwsectorcoronavirus

Janssens, S.R.M. and H. Prins, 2004. Hervormingen van het EU-landbouwbeleid: gevolgen voor de aardappelsector (Reform of the CAP: consequences for the potato sector; in Dutch). Den Haag, LEI (Wageningen Economic Research (LEI), Report 2.04.07.

Janssens, S.R.M., R. Hoste, W.H.M. Baltussen en F.H.J. Bunte, 2011. Handelsrelaties in de aardappelen varkenssector; De relatie tussen aanbieder en afnemer. LEI-rapport 2011-077

https://edepot.wur. nl/200516 
Janssens, B., R. van der Meer and B. Smit, 2020. Gevolgen van de coronacrisis voor de aardappelsector. Wageningen Economic Research, nota 2020-039f.

Jongeneel, R.A., 2018, Research for AGRI Committee - The CAP support beyond 2020: assessing the future structure of direct payments and the rural developments interventions in the light of the EU agricultural and environmental challenges, European Parliament, Policy Department for Structural and Cohesion Policies, Brussels.

Jongeneel, R., H. van Meijl, A. Gonzalez-Martinez, S. Moghayer, D. Cui, A. Tabeau, P. Berkhout (2021) Economische analyse van de impact van de COVID-19-crisis op de Nederlandse agrofoodsector voor de langere termijn (2020-2025). Wageningen, Wageningen Economic Research.

KWIN, 2018. Kwantitatieve Informatie Akkerbouw en Vollegrondsgroenteteelt (Quantitative Information Arable and field vegetable farming; in Dutch). Wageningen University and Research Field Crops.

Landbouwleven, 2021. Vlaanderen betaalde 5,19 miljoen euro coronacompensatie uit aan zwaar getroffen aardappeltelers. https://www.landbouwleven. be/10301/article/2021-03-08/vlaanderenbetaalde-519-miljoen-euro-coronacompensatie-uit-aan-zwaar-getroffen

Moggré, H., D. Cammaert and J. Wander, 2019. Loofdoding aardappelen; Resultaten veldproeven 2019 (Haulm killing potatoes; Results of field trials 2019l in Dutch). Delphy (independent advice organisation for arable farming in the Netherlands).

Montanari, F., I. Ferreira, F. Lofstrom, C. Varallo, S. Volpe, E. Smith, M. Kirova, A. Wion, U. Kubota, and J.D. Albuquerque, 2021, Research for Agri Committee - Preliminary impacts of the COVID-19 pandemic on European agriculture: a sector-based analysis of food systems and market resilience, European Parliament, Policy Department for Structural and Cohesion Policies, Brussels.

RVO, 2020. Tegemoetkoming-fritesaardappeltelers. https://www.rvo.nl/subsidie-en-

financieringswijzer/tegemoetkoming-fritesaardappeltelers

Smit, A.B., R.A. Jongeneel, H. Prins, J.H. Jager and W.H.G.J. Hennen, 2017, Impact of coupled EU support for sugar beet growing: More production, lower prices. Den Haag, Wageningen Economic Research, Report 2017-114, 62 pp. and Executive Summary 2017-114a.

https://www.wur.nl/nl/Publicatie-details. htm?publicationId=publication-way-353331323731

Staatscourant, 2020. Regeling tegemoetkoming land- en tuinbouwondernemers COVID-19. https://zoek. officielebekendmakingen. nl/stcrt-2020-25444. html

Toekomst GLB (Future of the CAP), 2021. GLB door de jaren heen (CAP througout the years; in Dutch). Website of the Dutch Ministry of Agriculture. www.toekomstglb.nl/over-glb/glb-door-dejaren-heen

Wallonia government, 2020. aide-exceptionnelle-pour-le-secteur-de-la-pomme-de-terre-a-la-suite-dela-pandemie-covid. https://agriculture.wallonie.be/-/aide-exceptionnelle-pour-le-secteur-de-lapomme-de-terre-a-la-suite-de-la-pandemie-covid--1?inheritRedirect=true

Wallonia Government, 2020a. Communique de presse aide exceptionnelle pour le secteur de la pomme de terre a la suite de la pandemie covid-19. https://agriculture.wallonie.be/-

/communique-de-presse-aide-exceptionnelle-pour-le-secteur-de-la-pomme-de-terre-a-la-suite-dela-pandemie-covid-19?inheritRedirect=true\&redirect $=\% 2$ Faccueil

Zezza, A., R. Henke, M. Lai, G. Petriccione, R. Solazzo, A. Sturla, A. Vagnozzi, S. Vanino, L. Viganò (CREA- PB), B. Smit, R. van der Meer, K. Poppe (Wageningen Economic Research), M. Lana, M. Weltin and A. Piorr (ZALF), 2016, Productivity vs sustainability: towards better support for viable and sustainable eu farms; research for agri committee of the European Parliament. Published by: Directorate-General for Internal Policies; Policy Department B - Structural and Cohesion Policies; Agriculture and Rural Development; www.europarl.europa.eu/RegData/etudes/STUD/2017/585905/IPOL_STU(2017)585905_EN.pdf

\section{Other sources:}

https://www. boerderij. nl/Akkerbouw/Blogs/2020/8/Volle-vrieshuizen-met-frites-werpen-schaduwvooruit-623984E/

https://www.boerderij.nl/Akkerbouw/Nieuws/2021/3/Belgen-produceerden-in-2020-ietsje-minderfrites-716162E/

https://www.boerenbond.be/actualiteit/noodfonds-corona-voor-de-aardappelsector-goedgekeurd https://lv.vlaanderen.be/nl/bedrijfsvoering/rampen-weersverzekering-en-

crisismaatregelen/crisismaatregelen/aardappelen 
Wageningen Economic Research P.O. Box 29703

2502 LS The Hague

The Netherlands

$\mathrm{T}+31(0) 703358330$

E communications.ssg@wur.nl

www.wur.eu/economic-research

Wageningen Economic Research REPORT

2021-062
The mission of Wageningen University \& Research is "To explore the potential of nature to improve the quality of life". Under the banner Wageningen University \& Research, Wageningen University and the specialised research institutes of the Wageningen Research Foundation have joined forces in contributing to finding solutions to important questions in the domain of healthy food and living environment. With its roughly 30 branches, $6,800$ employees ( $6,000 \mathrm{fte})$ and 12,900 students, Wageningen University \& Research is one of the leading organisations in its domain. The unique Wageningen approach lies in its integrated approach to issues and the collaboration between different disciplines. 



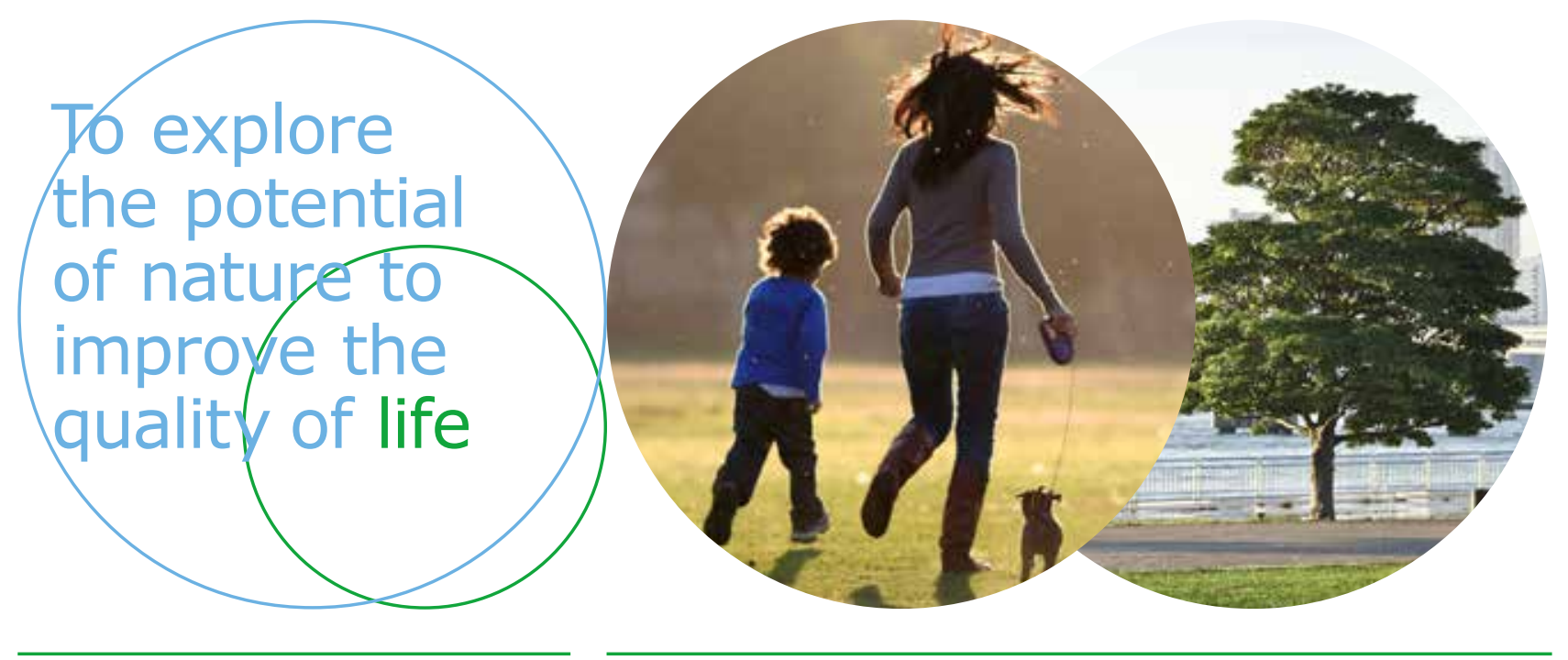

Wageningen Economic Research P.O. Box 29703

2502 LS Den Haag

The Netherlands

$\mathrm{T}+31(0) 703358330$

E communications.ssg@wur.nl

www.wur.eu/economic-research

Report 2021-062

ISBN 978-94-6395-981-0
The mission of Wageningen University \& Research is "To explore the potential of nature to improve the quality of life". Under the banner Wageningen University \& Research, Wageningen University and the specialised research institutes of the Wageningen Research Foundation have joined forces in contributing to finding solutions to important questions in the domain of healthy food and living environment. With its roughly 30 branches, 6,800 employees $(6,000 \mathrm{fte})$ and 12,900 students, Wageningen University \& Research is one of the leading organisations in its domain. The unique Wageningen approach lies in its integrated approach to issues and the collaboration between different disciplines. 